\title{
ISTORIJA
}

\section{LIETUVOS STEIGIAMOJO SEIMO SENIŪNŲ SUEIGA: VYRESNIUৃJŲ KONVENTO VEIKLOS GAIRĖS}

Dr. Vilma Akmenyté-RuzgienĖ

Lietuvos Respublikos Seimo kanceliarija,

Parlamentarizmo istorines atminties skyrius

Office of the Seimas of the Republic of Lithuania, Unit for Historical Memory of Parliamentarianism Gedimino pr. 53, 01109 Vilnius El.paštas vilma.ruzgiene@lrs.lt

\section{Santrauka}

Lietuvos Steigiamajame Seime be kitų struktūrinių vienetų veikè Seniūnų sueiga, suburta Steigiamojo Seimo Prezidiumo iniciatyva opiausiems Seimo darbo organizavimo klausimams spręsti: Seimo posedžių organizavimo, Seimo statuto, Seimo narių darbo sąlygų, teikti siūlymus Seimui dèl Seimo komisijų veiklos ir kt. Seniūnų sueigą sudare visų frakcijų atstovai, ryškūs, skirtingos visuomeninès ir politinès patirties, skirtingo išsilavinimo, skirtingų profesijų.

Reikšminiai žodžiai: Lietuvos Steigiamasis Seimas, Seniūnų sueiga, Seimo Prezidiumas, Seimo statutas, frakcijos, parlamentas.

\section{Ivadas}

2020-ieji yra išskirtiniai metai Lietuvos valstybès istorijoje, šiemet minima ypatinga sukaktis - Lietuvos Respublikos 100-metis. Atsikurianti Lietuvos valstybè dar nebuvo pasirinkusi santvarkos, o teisę 
nuspręsti, kokị raidos kelią rinksis valstybè, turèjo tik demokratiškai visų jos piliečių išrinktas Steigiamasis Seimas. Šią teisę ir prievolę Steigiamajam Seimui dar 1918 m. vasario 16-ąją pavedè Lietuvos Taryba. Nors būta svyravimų, o 1918 metais net bandymų ịteisinti Lietuvą kaip monarchiją, 1920 m. gegužès 15 dieną laikinojoje Lietuvos sostinejje Kaune susirinkęs Steigiamasis Seimas dar kartą visų Lietuvos piliečių vardu iškilmingai proklamavo Lietuvos valstybės nepriklausomybę ir Lietuvą paskelbè demokratine respublika. Retas susimąsto, kaip reikšmingai ši data persipina su kita Lietuvai svarbia šių metų sukaktimi - Lietuvos Nepriklausomybès atkūrimo 30-mečiu. O juk 1990 m. kovo 11-osios Lietuvos Nepriklausomybės Akte yra ittvirtinta, kad 1918 m. vasario 16 d. Lietuvos Nepriklausomybès Aktas ir 1920 m. gegužès 15 d. Steigiamojo Seimo rezoliucija niekada nebuvo nustoję teisinès galios ir yra Lietuvos valstybės konstitucinis pamatas.

Amžininkai Lietuvos Steigiamąji Seimą vadino vilčių parlamentu, būtent šiai Seimo kadencijai buvo pavesta parengti pamatus pagrindinėms valstybės reformoms ir nubrèžti gaires tolimesniam Lietuvos valstybès raidos keliui. $1926 \mathrm{~m}$. birželio $2 \mathrm{~d}$. atidarydamas Lietuvos Respublikos Trečiąji Seimą, Respublikos Prezidentas Aleksandras Stulginskis pabrèžè: „Lietuvos Steigiamasis Seimas, išleisdamas šaliai valstybès konstituciją, nustate šalies valdymo formą, padejo šaliai tvarkytis reikalingus pagrindus. Steigiamojo Seimo susirinkimu prasidejo Lietuvos parlamentarinis demokratinès valstybės gyvenimas, tai, be abejo, didžiausios reikšmès įvykis mūsų tautos ir valstybès gyvenime." ${ }^{\text {"T }}$ Todèl šiame straipsnyje siekiama panagrinèti pirmojo visuotiniuose ir demokratiniuose rinkimuose išrinkto Lietuvos parlamento - Steigiamojo Seimo darbo organizavimą.

Straipsnio tikslas - apžvelgti Lietuvos Steigiamojo Seimo (19201922 m.) Seniūnų sueigos sudarymo aplinkybes, nustatyti Seniūnų sueigos sudètị ir narių kaitą, apibūdinti kolektyvinị jų portretą,

1926 m. birželio 2 d., 1 posėdis, Seimo stenogramos, [Kaunas], 1922-1927. 
apžvelgti Seniūnų sueigoje svarstytų klausimų spektrą. Tyrimo chronologija apima vos trejus metus - Steigiamojo Seimo kadenciją 1920-1922 m., tačiau šis laikotarpis buvo turtingas ịvykių, nulėmusių tolimesnę Lietuvos parlamento raidą. Šiuo laikotarpiu formavosi moderniojo Lietuvos parlamentarizmo tradicijos.

Istoriografijoje Steigiamojo Seimo Seniūnų sueiga nèra specialiai tyrinèta, atskiruose tyrimuose pateikiama pirmoji jos sudetis ir lakoniškai pristatomas veikimo principas ${ }^{2}$. Parlamentarų biografijo$\mathrm{se}^{3}$ taip pat tik lakoniškai paminima, kad jie ejo pareigas ir Seniūnų sueigoje, tačiau nedetalizuojama, kada iš jos pasitraukè. Steigiamojo Seimo Seniūnų sueiga nèra reflektuojama buvusių parlamentarų prisiminimuose ir autobiografijose ${ }^{4}$.

\section{Seniūnų sueigos dokumentų apžvalga}

Tyrimą sunkina skurdi šaltinių bazè. Stebètina, tačiau išliko nedaug demokratinio laikotarpio Lietuvos Respublikos Seimo (1920-1927 m.) dokumentų arba apie juos dar kol kas nežinoma. Nèra bendro archyvinio 1920-1927 m. Lietuvos Respublikos Seimo dokumentų fondo. Kiek leidžia spręsti publikuoti šaltiniai, kuriuose

2 Truska, L. Steigiamasis Seimas ir jo vieta Naujujų laikų Lietuvos istorijoje. Lietuvos Steigiamojo Seimo (1920-1922 metu) nariu biografinis žodynas. Sudarè A. Ragauskas, M. Tamošaitis, Vilnius: Vilniaus pedagoginio universiteto leidykla, 2006, p. 31-32; Blažytè-Baužienė, D., Tamošaitis, M., Truska, L. Lietuvos Seimo istorija. XX-XXI a. pradžia, Vilnius: Baltos lankos, 2009; Daugirdaitė-Sruogienė, V. Lietuvos Steigiamasis Seimas. New York: Tautos fondas, 1975; Čepėnas, P. Naujuju laiku Lietuvos istorija. T. 2, Vilnius, 1992.

3 Lietuvos Steigiamojo Seimo (1920-1922 metu) nariu biografinis žodynas. Sudare A. Ragauskas, M. Tamošaitis, Vilnius: Vilniaus pedagoginio universiteto leidykla, 2006; Eidintas, A. Aleksandras Stulginskis ir jo epocha. Vilnius: Mokslo ir enciklopediju leidybos centras, 2014; Eidintas, A. Aleksandras Stulginskis: Lietuvos Prezidentas - Gulago kalinys, Vilnius, 1995; Būtènas, J., Mackevičius, M. Mykolas Sleževičius: advokatas ir politikas. Vilnius: Lietuvos rašytojų sajungos leidykla, 1995.

4 Staugaitis, J. Mano atsiminimai. Vilnius, 2006; Krupavičius, M. Atsiminimai. Chicago, Ill.: Lietuviškos knygos klubas, 1972. 
užsimenama apie raštvedybos ir dokumentacijos vedimo taisykles, tai - Seimo statutai, Seimo stenogramos - išties turètume turèti labai gausų ir išsamų dokumentų rinkinị, tarp jų ir Seniūnų sueigos protokolus. Kiekvienas Seimo struktūrinis padalinys, Seimo komisijos ir subkomisijos bei Seimo raštinè turejjo rengti savo veiklos dokumentus. Apie šių dokumentų išsamumą leidžia spręsti Steigiamojo Seimo Sveikatos subkomisijos posèdžių protokolai, publikuoti specializuotame medikams skirtame žurnale „Medicina“" Tokių išsamių protokolų publikacijos nuteikia viltingai, nes turèjo būti panaši ir Steigiamojo Seimo Seniūnų sueigos dokumentacija, tačiau šiandien pasiekiamų šaltinių bazès situacija nuvilia - yra išlikę pavieniai Steigiamojo Seimo seniūnų sueigos dokumentai - iliustruojantys anuomet vykusią tarpinstitucinę komunikaciją - jų galima aptikti Lietuvos centriniame valstybès archyve saugomame Lietuvos Respublikos Ministrų Kabineto fonde - F. 923. Todèl pagrindine šaltinių baze tampa Steigiamojo Seimo posèdžių stenogramos, anuomet publikuotos „Steigiamojo Seimo darbų“6 pavadinimu. Tačiau net ir skaitant Steigiamojo Seimo Stenogramas tenka įvertinti riziką dèl šaltinio patikimumo: pavyzdžiui, ta pačia data - $1922 \mathrm{~m}$. balandžio 8-ąja - yra pažymėtos net trys Steigiamojo Seimo stenogramos, tai leidinio „Steigiamojo Seimo darbai“ 40-ame sąsiuvinyje publikuotos 194-o posėdžio ${ }^{7}$ (pradžia - 9.56 val., pabaiga - 14 val. 33 min.) ir 195-o posèdžio ${ }^{8}$ (pradžia - 10 val., pabaiga - 15 val. 10 min.) stenogramos, bei 41-ame sąsiuvinyje publikuota $198-\mathrm{o}^{9}$ posèdžio (pradžia - 9 val. 54 min., pabaiga - 12.40 val.) stenograma. Stenogramose

5 Iš St. Seimo sveikatos subkomisijos, Medicina, 1920, Nr. 2, p. 54-57; ten pat, Nr. 3, p. 77-88; ten pat, Nr. 4, p. 113-119; ten pat, Nr. 5, p. 145-148, ten pat, Nr. 6, p. 177-180; ten pat, Nr. 7, p. 207-211.

6 Steigiamojo Seimo darbai, Kaunas: St. Seimo sekretoriatas, 1920-1922 (toliau SSD).

71922 m. balandžio mèn. 8 dieną, I Sesijos, 194 posèdis. SSD. Sąs. 40, p. 55.

81922 m. balandžio mèn. 8 dieną, I Sesijos, 195 posèdis. SSD. Sąs. 40, p. 75.

91922 m. balandžio mèn. 8 dieną, I Sesijos, 198 posėdis. SSD. Sąs. 41, p. 32. 
ịrašytas posėdžių laikas rodo, kad posėdžiai tikrai vyko skirtingomis dienomis. Tarp šių posėdžių vykę du kiti Seimo posėdžiai datuoti tvarkingiau: 196-o posėdžio stenograma pažymèta $1922 \mathrm{~m}$. balandžio $10 \mathrm{~d} .{ }^{10}$, o 197-as posėdis - $1922 \mathrm{~m}$. balandžio $11 \mathrm{~d} .{ }^{11}$. Panašių neatitikimų yra ir daugiau. Tokia chaotiška šaltinių būklè neleidžia visiškai ir patikimai rekonstruoti Steigiamojo Seimo struktūrinių vienetų: komisijų, subkomisijų sudèties. Seniūnų Sueigos sudèties kaita buvo fiksuojama Steigiamojo Seimo stenogramose. Tik po to, kai Seimo posėdyje būdavo pranešama apie frakcijos sprendimą pakeisti jos atstovą Seniūnų sueigoje ir po to, kai Seimas nubalsuodavo, tik nuo tos akimirkos frakcijos atstovas ịgydavo Seniūnų sueigos nario igaliojimus. Keičiant Seniūnų sueigos narị būdavo ịvardijama, kuris frakcijos kolega ji pakeičia. Steigiamojo Seimo stenogramos šiuo požiūriu yra gana lakoniškos, dažnai nurodoma tik Seimo nario pavardè (tai nèra problema, jei ta pačia pavarde yra tik vienas Seimo narys, tačiau pasitaikè, kad tą pačią pavardę turẻjo net trys Seimo nariai), kartais nèra nurodoma, kurị kolegą pakeitè būsimas Seniūnų sueigos narys. Ivertinus šaltinių keliamus iššūkius, šis tyrimas galètų pasitarnauti išsamesniems ir detalesniems ateities tyrimams.

\section{Seimo struktūros apžvalga}

Steigiamojo Seimo struktūriniai vienetai buvo Seimo Prezidiumas, kurị sudarė 7 nariai: Seimo Pirmininkas, du vicepirmininkai (pirmasis ir antrasis), du sekretoriai (pirmasis ir antrasis), turintys sprendžiamąji balsą, ir du sekretoriai (pirmasis ir antrasis), turintys patariamąji balsą. Institucinèje Seimo veikloje Steigiamojo Seimo Pirmininkas buvo vienas iš septynių Steigiamojo Seimo Prezidiumo narių, kuriam buvo pavesta pirmininkauti Steigiamojo Seimo posėdžiams ir atstovauti Steigiamajam Seimui.

101922 m. balandžio mèn. 10 dieną, I Sesijos, 196 posėdis. SSD. Sąs. 40, p. 1.

111922 m. balandžio mèn. 11 dieną, I Sesijos, 197 posėdis. SSD. Sąs. 41, p. 1. 
Steigiamojo Seimo nariai dirbo susibūrę ị frakcijas. Frakcija - politinès partijos narių grupé, igyvendinanti savo partijos tikslus ir politiką parlamente. Steigiamajame Seime frakciją galejo sudaryti mažiausiai trys Seimo nariai. Lietuvos Steigiamojo Seimo statutas numate, kad tik po to, kai frakcijos narių sąrašas būdavo pristatomas posėdžio metu ir iregistruojamas Seimo Prezidiume, frakcija oficialiai pradedavo veiklą. Seime veikè iš įvairių frakcijų sudarytas Lietuvos krikščionių demokratų blokas, jị sudarè susijungusios Ūkininkų sąjungos, Darbo federacijos, Lietuvių katalikių moterų, Lietuvos krikščionių demokratų partijos frakcijos (bloką sudarė 59 nariai) ir Valstiečių liaudininkų blokas, jị sudarè susijungusios Lietuvos socialistų liaudininkų demokratų ir Lietuvos valstiečių sąjungos frakcijos (iš pradžių ši bloką sudarẻ 29 Seimo nariai, vẻliau, vienam Seimo nariui pasitraukus, frakcija sumažèjo iki 28 narių). Atskirai veikẻ Lietuvos socialdemokratų frakcija (iš pradžių ją sudarė 14 Seimo narių, vèliau, pasitraukus vienam Seimo nariui, frakcija sumažejo iki 13 narių), Žydų frakcija (ją sudarè 6 Seimo nariai), Lenkų frakcija (ją sudarè 3 Seimo nariai), Lietuvos vokiečių komiteto atstovas frakcijos sudaryti negalejo, taip pat per visą Steigiamojo Seimo kadenciją buvo du Seimo nariai, nepriklausę jokiai frakcijai.

Svarbų vaidmenį organizuojant Steigiamojo Seimo darbą atliko nuolatinės ir laikinosios komisijos. Šiandien anuometinių nuolatinių komisijų darbą atlieka Seimo komitetai. Jų užduotis buvo parengti arba apsvarstyti plenariniams posėdžiams teikiamų ịstatymų projektus. Steigiamojo Seimo kadencijos metu veikẻ keliolika nuolatinių komisijų, jos rūpinosi Konstitucijos, krašto apsaugos, žemès reformos, finansų, švietimo, socialinės apsaugos, užsienio reikalų, savivaldybių, prekybos, pramonès, ūkio ir kitais klausimais. Be nuolatinių, buvo sudaromos ir laikinosios komisijos ịvairių ịvykių aplinkybėms ištirti. Komisijos atlikdavo svarbų ịstatymų rengimo darbą. Istatymo sumanymas būdavo perduodamas atitinkamai komisijai, ši jị apsvarsčiusi teikdavo tolesniam svarstymui Seimo posėdyje arba siūlydavo sumanymą atmesti. İstatymo projektai po pirmojo ir antrojo skaitymo 
plenariniame Seimo posèdyje būdavo perduodami atitinkamai komisijai, o kartu ir Bendrosios teisès komisijai. Po įstatymo projekto trečiojo skaitymo plenariniame Seimo posėdyje istatymas būdavo perduodamas Redakcijos komisijai.

Sklandesniam visų struktūrinių vienetų darbui užtikrinti buvo i̊steigta ir Seniūnų sueiga.

\section{Steigiamojo Seimo Seniūnų sueigos sudarymo aplinkybès}

Šių laikų Lietuvos Respublikos Seime veikia Seniūnų sueiga, sudaryta iš daugiau nei 20-ies Seimo narių - Seimo valdybos narių ir frakcijų atstovų. $1994 \mathrm{~m}$. vasario $17 \mathrm{~d}$. buvo priimtas Lietuvos Respublikos Seimo statutas, su pakeitimas galiojantis ir šiandien, jis numato, kad Seniūnų sueigos nariai privalo dalyvauti sueigos posėdžiuose ir skelbia: „Pagrindinis Seniūnų sueigos uždavinys - svarstyti Seimo sesijos darbų programas bei posėdžių darbotvarkes ir pritarti joms, derinti Seimo komitetų ir frakcijų darbo organizavimo klausimus, teikti sprendimų šiais klausimais projektus Seimui bei valdybai, taip pat patarimus Seimo Pirmininkui." ${ }^{12}$ Seniūnų sueiga buvo sudaryta ir Lietuvos Steigiamajame Seime.

Steigiamajame Seime Seniūnų sueiga buvo sudaryta ne iš karto. 1920 m. gegužès 15 d. 1-ame Lietuvos Steigiamojo Seimo posėdyje buvo išrinkti tik du Seimo prezidiumo nariai: Steigiamojo Seimo Pirmininkas Aleksandras Stulginskis ir pirmasis sekretorius Ladas Natkevičius $^{13}$. 1920 m. gegužès 17 d. 2-ame Steigiamojo Seimo posèdyje toliau buvo renkami Steigiamojo Seimo Prezidiumo nariai ${ }^{14}$.

${ }^{12}$ Lietuvos Respublikos Seimo statutas. Vilnius, 1994 m. vasario 17 d., Nr. I-399, Teisès aktų registras, galiojanti suvestinè redakcija: 2020-06-17-2020-12-31, Teisès aktų registras, https://www.e-tar.lt/portal/lt/legalAct/TAR.123B53F30F70/asr

131920 m. gegužès 15 d., 1 posèdis. $S S D$.

141920 m. gegužès 17 d., 2 posèdis. SSD. 
Tos pačios dienos posėdyje buvo sudaryta Steigiamojo Seimo statuto komisija, turinti parengti pagrindinị dokumentą, reglamentuosiantị Steigiamojo Seimo darbą - Steigiamojo Seimo statutą. Sudaryti šią komisiją pasiūlè Lietuvos krikščionių demokratų bloko vardu kalbèjęs Mykolas Krupavičius. Seimui pritarus, Komisiją sudare 7 atstovai: Lietuvos socialistų liaudininkų demokratų ir Lietuvos valstiečių sąjungos frakcijų bloko atstovai Vladas Lašas ir Matas Untulis, Socialdemokratų frakcijos atstovas Vladas Požela, Žydų frakcijos atstovas Maksas Soloveičikas, Lietuvos krikščionių demokratų bloko atstovai Valdemaras Vytautas Čarneckis, Justinas Staugaitis ir Vytautas Bičiūnas ${ }^{15}$.

Ši komisija turèjo labai mažai laiko užduočiai atlikti. Jau kitą dieną - 1920 m. gegužès 18 d. 3-iame Steigiamojo Seimo posėdyje buvo pristatytas Laikinojo Steigiamojo Seimo Statuto projektas ${ }^{16}$. Šiuos du posėdžius skyrè vos daugiau nei 24 valandų pertrauka (šio laiko turejjo užtekti ir nakties poilsiui). 3-iasis Seimo posèdis prasidèjo vakare - 18 val. 25 min. ${ }^{17}$ Ir nors Statutas turèjo būti svarstomas pirmuoju dienos klausimu, tačiau, tikètina, kad dar vyko paskutiniai redakciniai pataisymai, todèl pirmiausia buvo svarstytas paskutinis tos dienos dienotvarkèje įrašytas klausimas - Seimo komisijų sudarymas. Po jo buvo svarstytas ir priimtas Statutas. Laikinojo Steigiamojo Seimo statuto projektą pristatęs Valdemaras Vytautas Čarneckis atsiprašè Seimo narių, kad jiems teko skaityti Statuto projekto rankraštį: „St. Seimo statuto projekto komisija atsiprašo, kad dèl laiko trūkumo negalejo prirengti spausdinto projekto." ${ }^{18}$ Projekto pristatymas vyko gana sklandžiai, su nedidelemis diskusijomis ir teksto korekcijomis. Tos pačios dienos posėdyje įvyko ir projekto pateikimas ir balsavimas. Nors buvo siūlyta trečiąji Statuto projekto skaitymą ir galutinị balsavimą atidèti kitam posèdžiui, tačiau Seimui nubalsavus Laikinasis

151920 m. gegužès 17 d., 2 posèdis. SSD.

161920 m. gegužès 18 d., 3 posèdis. SSD.

171920 m. gegužès 18 d., 3 posèdis. SSD.

181920 m. gegužès 18 d., 3 posèdis. SSD. 
Steigiamojo Seimo statutas buvo priimtas vėlyvą 1920 m. gegužès 18 d. vakarą. Laikinasis Steigiamojo Seimo Statutas, be kitų Seimo struktūros vienetų, numatė ir Seimo Seniūnų sueigos sudarymą. Vèliau laikas parodè, kad būtent Seniūnų sueigai teko didžioji našta peržiūrèti ir redaguoti Laikinąji Steigiamojo Seimo statutą bei rengti nuolatinị Seimo statuto variantą.

Laikinojo Steigiamojo Seimo statuto pagrindu tapo Lietuvos Valstybès Tarybos statutas ${ }^{19}$. Tikètina, kad dar iki susirenkant Steigiamajam Seimui buvo priimtas principinis sprendimas būtent ši statutą pritaikyti Seimo veikloje. Tuo labiau, kad Steigiamasis Seimas tapo savitu Lietuvos Valstybès Tarybos veiklos tęseju. Tarp Steigiamojo Seimo statuto komisijos narių buvo gerai su Lietuvos Valstybės Tarybos darbu ir jo statutu susipažinę buvę Lietuvos Valstybės Tarybos nariai Valdemaras Vytautas Čarneckis ir Justinas Staugaitis (išrinktas ir Steigiamojo Seimo antruoju vicepirmininku, jis buvo ir $1918 \mathrm{~m}$. vasario $16 \mathrm{~d}$. Lietuvos Nepriklausomybès Akto signataras).

Lietuvos Steigiamojo Seimo statute buvo rašoma, kad sèkmingesniam Seimo darbui organizuoti yra steigiama Seniūnų sueiga ${ }^{20}$, ir toliau detalizuojama: „Seniūnų sueiga susideda iš frakcijų atstovų ir Steigiamojo Seimo Prezidiumo. “21

Seimo vicepirmininkas Jonas Staugaitis, pabrèždamas Seniūnų sueigos svarbą, jau 6-ame Steigiamojo Seimo posèdyje sakè: „Prašyčiau, kad seniūnų sueigos klausimas taip pat nebūtų atidedamas. Jis užima labai maža laiko, o mum jis [Seniūnų sueigos sudarymas - red.]

19 Truska, L. Steigiamasis Seimas ir jo vieta Naujujų laikų Lietuvos istorijoje. Lietuvos Steigiamojo Seimo (1920-1922 metu) nariu biografinis žodynas. Sudarè A. Ragauskas, M. Tamošaitis, Vilnius: Vilniaus pedagoginio universiteto leidykla, 2006, p. 31-32.

${ }^{20}$ Lietuvos Steigiamojo Seimo statutas. Steigiamojo Seimo priimtas $1920 \mathrm{~m}$. gegužès mèn. 18 d., papildytas liepos mèn. 9 d., einantis Respublikos Prezidento Pareigas Steigiamojo Seimo Pirmininkas Aleksandras Stulginskis ir Ministras Pirmininkas Kazys Grinius pasirašè 1921 m. rugsèjo 14 d. Vyriausybès žinios. 1921, Nr. 71, p. 1-5.

${ }^{21}$ Ten pat. 
yra labai svarbus, nes yra reikalų, kurių prezidiumas be Seimo atstovų spręst negali“22. Deja, Seimo posedyje nebuvo detalizuota, kokių neatidèliotinų „reikalų“ Seimo Prezidiumas negalejo spręsti be Seimo narių pagalbos ir pritarimo, tačiau peržvelgus Steigiamojo Seimo posėdžių stenogramas akivaizdu, kad dauguma klausimų buvo apie Steigiamojo Seimo darbo organizavimą. Taigi, tą pačią dieną, $1922 \mathrm{~m}$. gegužès 22-ąją, be diskusijų buvo patvirtinti frakcijų deleguoti atstovai ị Seniūnų sueigą ir taip buvo sudarytas šis struktūrinis Seimo vienetas.

Lietuvos Steigiamojo Seimo statutas skelbè: „Kiekviena frakcija Seniūnų Sueigon skiria savo narių, didesnès frakcijos nuo 10 narių siunčia po vieną atstovą. Likučiai, didesni kaip 5, skaitomi pilna dešimtimi. "23 Frakcijos, kurias sudarè mažiau nei 10 narių, ị Seniūnų sueigą deleguodavo po vieną narị. Iš viso Steigiamojo Seimo Seniūnų sueigą sudarè 19 parlamentarų: 7 Steigiamojo Seimo Prezidiumo nariai ir 12 frakcijų atstovų (iš jų 6 Krikščionių demokratų bloko atstovai, 3 Valstiečių liaudininkų bloko atstovai, 1 Socialdemokratų frakcijos atstovas, 1 Žydų frakcijos atstovas ir 1 lenkų atstovas ${ }^{24}$. Steigiamojo Seimo statutas numaté, kad Seniūnų sueiga privalo išsirinkti trijų asmenų prezidiumą, koordinuojantị jos veiklą ${ }^{25}$. Deja, dèl menkai išlikusios 1920-1940 m. Lietuvos Respublikos Seimo, ypač Lietuvos Steigiamojo Seimo, šaltinių bazès kol kas neįmanoma rekonstruoti, kurie Seimo nariai sudarè Seniūnų sueigos prezidiumą, tačiau yra žinoma, kad Seniūnų sueigos pirmininku buvo išrinktas Jonas Staugaitis ${ }^{26}$, kartu èjęs ir Steigiamojo Seimo pirmojo vicepirmininko pareigas.

221920 m. gegužès 22 d., 6 posèdis. SSD.

$231920 \mathrm{~m}$. gegužès $18 \mathrm{~d}$., 3 posèdis. SSD.

241920 m. gegužès 22 d., 6 posèdis. $S S D$.

251920 m. gegužès $18 \mathrm{~d}$., 3 posèdis. $S S D$.

${ }^{26} 1920$ m. gegužès 28 d., 8 posèdis; 1921 m. lapkričio 25 d., 143 posėdis. SSD. 


\section{Seniūnų sueigą ịejo septyni Steigiamojo Seimo Prezidiumo nariai:}

Aleksandras Stulginskis, Steigiamojo Seimo Pirmininkas, Krikščionių demokratų bloko atstovas;

Jonas Staugaitis, pirmasis vicepirmininkas, Lietuvos socialistų liaudininkų demokratų ir Lietuvos valstiečių sąjungos frakcijų bloko atstovas;

Justinas Staugaitis, antrasis vicepirmininkas, Krikščionių demokratų bloko atstovas;

Ladas Natkevičius, pirmasis sekretorius, turintis sprendžiamąji balsą, Lietuvos socialistų liaudininkų demokratų ir Lietuvos valstiečių sąjungos frakcijų bloko atstovas (vèliau ji pakeitè Vytautas Račkauskas);

Petras Radzevičius, antrasis sekretorius, turintis sprendžiamąji balsą, Krikščionių demokratų bloko atstovas (vėliau jị pakeitė Antanas Milčius);

Bronislovas Cirtautas, sekretorius, turintis patariamąji balsą, Socialdemokratų frakcijos atstovas;

Naftalis Fridmanas, sekretorius, turintis patariamąji balsą, Žydu frakcijos atstovas (vèliau ji pakeitè Nachmanas Rachmilevičius).

1920 m. gegužès 22 d. Seniūnų sueigos nariais buvo išrinkti šie dvylika parlamentarų: ${ }^{27}$

Jonas Vailokaitis, Krikščionių demokratų bloko atstovas (vẻliau ji Seniūnų sueigoje pakeitė Antanas Šmulkštys);

Zigmas Starkus, Krikščionių demokratų bloko atstovas;

${ }^{27} 1920$ m. gegužès 22 d., 6 posèdis. SSD. 
Kazimieras Bizauskas, Krikščionių demokratų bloko atstovas (vèliau jị Seniūnų sueigoje pakeitė Antanas Tumènas, ši pakeitė Valdemaras Vytautas Čarneckis);

Kazimieras Jokantas, Krikščionių demokratų bloko atstovas;

Kazimieras Ambrozaitis, Krikščionių demokratų bloko atstovas;

Mykolas Krupavičius, Krikščionių demokratų bloko atstovas (vėliau jị Seniūnų sueigoje pakeitè Vladas Jurgutis);

Kazys Grinius, Lietuvos socialistų liaudininkų demokratų ir Lietuvos valstiečių sąjungos frakcijų bloko atstovas (vèliau jị Seniūnų sueigoje pakeitė Jonas Makauskas);

Motiejus Petrauskas, Lietuvos socialistų liaudininkų demokratų ir Lietuvos valstiečių sąjungos frakcijų bloko atstovas (vèliau jị Seniūnų sueigoje pakeitė Vladas Lašas);

Matas Untulis, Lietuvos socialistų liaudininkų demokratų ir Lietuvos valstiečių sąjungos frakcijų bloko atstovas (vèliau ji Seniūnų sueigoje pakeitė Mykolas Sleževičius);

Kazimieras Venclauskis, Socialdemokratų frakcijos atstovas (1921 m. gegužès $20 \mathrm{~d}$. frakcijos sprendimu buvo atšauktas iš Seniūnų sueigos, vèliau ji pakeitè Stasys Digrys);

Maksas Soloveičikas, Žydų frakcijos atstovas (vèliau jị Seniūnų sueigoje pakeitè Ozeris Finkelšteinas, o ši pakeitė Simonas Rozenbaumas);

Antanas Šnielevskis, lenkų atstovas (nuo $1921 \mathrm{~m}$. liepos 9 d. Steigiamojo Seimo darbe nebedalyvavo).

$1921 \mathrm{~m}$. liepos 9 d. ị Seniūnų sueigą pavaduojančiais nariais buvo deleguoti Krikščionių demokratų bloko atstovai Eliziejus Draugelis, Antanas Bulionis ir Julius Kaupas bei Valstiečių liaudininkų bloko at- 
stovai Jonas Kriščiūnas ir Vytautas Račkauskas ${ }^{28}$. Pavaduojantys nariai dalyvaudavo Seniūnų sueigos posèdžiuose, kai juose negalèdavo dalyvauti tikrieji nariai.

Nors iš viso Steigiamojo Seimo Seniūnų sueigą sudarè 19 narių, tačiau per visą Steigiamojo Seimo kadenciją Seniūnų sueigos nariais yra buvę 37 parlamentarai: 17 Krikščionių demokratų bloko atstovų, 11 Valstiečių liaudininkų bloko atstovų, 3 socialdemokratai, 5 Žydų frakcijos atstovai ir 1 lenkų atstovas. Visi jie paliko ryškų íspaudą Lietuvos parlamento istorijoje (visas Seniūnų sueigos narių sąrašas frakcijomis - žemiau tekste).

\section{Steigiamojo Seimo Seniūnų sueigos veikla}

1921 m. gegužès 15 d. iškilmingame Steigiamojo Seimo posėdyje, skirtame Lietuvos Steigiamojo Seimo susirinkimo pirmosioms metinėms paminèti, Seimo Pirmininkas Aleksandras Stulginskis, apžvelgdamas parlamento darbą, paminejjo: „Tuo pačiu metu dirbo pagelbinès Steigiamojo Seimo ịstaigos: prezidiumas, Seniūnų sueiga, komisijos. "29 Seniūnų sueiga buvo vienas iš Steigiamojo Seimo struktūrinių vienetų, kuriame buvo sprendžiami Seimo darbo organizavimo klausimai, kartais jị Seimo nariai pavadindavo „konventu“, „seniūnų konventu“30, Mykolas Krupavičius yra vadinęs ir „Senior Konventu“31. Lotynų kalbos žodis „konventas“ dažniausiai vartojamas svarbiausius klausimus spręsti ịgaliotų asmenų susirinkimui įvardyti. Būtent tokią funkciją atliko Seniūnų sueiga - sprendè svarbiausius Steigiamojo Seimo darbo organizavimo klausimus: Seimo posėdžių organizavimo, Seimo statuto, Seimo narių darbo sąlygų sudarymo klausimus, teikè

${ }^{28} 1921 \mathrm{~m}$. liepos 9 d., 117 posèdis. SSD.

291921 m. gegužès 15 d., Iškilmingas Steigiamojo Seimo posėdis metinėm sukaktuvėm paminèti. SSD.

301920 m. birželio 16 d., 16 posèdis; 1920 m. spalio 1 d., 47 posèdis. SSD.

${ }^{31} 1920$ m. rugpjūčio 10 d., 37 posèdis. $S S D$. 
siūlymus Seimui dèl Seimo komisijų veiklos, komisijų sujungimo, narių komisijose skaičiaus, teike siūlymus darbotvarkès pakeitimams, esant reikalui nustatydavo darbotvarkès prioritetus ir pan. ${ }^{32}$ Seniūnų sueiga svarstė klausimą dèl valstybės biudžeto svarstymo tvarkos ir nustatẻ biudžeto svarstymo eigą ${ }^{33}$. Seniūnų sueigoje buvo derinami, vèliau Seime priimami ir Steigiamojo Seimo vardu platinami atsišaukimai, raginantys piliečius susitelkti krašto gynybai ar palaikyti Lietuvos ekonomiką ịsigyjant valstybès platinamus paskolos lakštus. Steigiamojo Seimo Prezidiumas parengdavo atsišaukimo tekstą, ji perduodavo apsvarstyti Seniūnų sueigai, o ši galutinị redagavimą pavesdavo specialiai sudarytai komisijai, ši peržiūrètą dokumento tekstą perduodavo frakcijoms svarstyti ${ }^{34}$. Steigiamojo Seimo atsišaukimų tekstai buvo svarstyti $1920 \mathrm{~m}$. birželị ir liepą ${ }^{35}$ ir dažniausiai būdavo susiję su Lietuvos ir Lenkijos konfliktu dèl Vilniaus. 1920 m. vasarą Lietuvos kariuomenei ịžengus ị Vilnių, buvo planuota kreiptis Seimo vardu i Rytų Lietuvos gyventojus, paaiškinant: „[...], kad naujai atėjusi mūsų valdžia duos jiems ramaus, tveriamojo gyvenimo sąlygų, užtikrins piliečių ramybę, sutvarkys šalị. " ${ }^{36}$ Tačiau jautri geopolitinė situacija vertẻ Seniūnų sueigą elgtis apdairiai, todèl net keliuose sueigos posėdžiuose svarstytas Steigiamojo Seimo atsišaukimo ị Rytų Lietuvos gyventojus projektas taip ir nebuvo parengtas. $1920 \mathrm{~m}$. rugsejo 4 d. Seniūnų sueigos pirmininkas Jonas Staugaitis kreipèsi ị Ministrą Pirmininką prašydamas tokį atsišaukimą išplatinti Vyriausybès vardu: „Steigiamojo Seimo Seniūnų Sueiga keliuose savo posėdžiuose

32 ,Seniūnų Sueigos nutarimu pripažintas skubotu Amato, kredito, prekybos, pramonès ir koperacijos įstaigų bendrų pajamų mokesnio įstatymo sumanymas“, žr. $1921 \mathrm{~m}$. kovo $16 \mathrm{~d}$., 73 posėdis, $1921 \mathrm{~m}$. lapkričio $25 \mathrm{~d}$., 143 posėdis. $S S D$.

$331921 \mathrm{~m}$. lapkričio $11 \mathrm{~d}$., 139 posèdis. SSD.

$341920 \mathrm{~m}$. birželio 7 d., 12 posèdis. SSD.

351920 m. liepos 28 d., 32 posėdis. SSD.

36 Steigiamojo Seimo Seniūnų sueigos pirmininko Jono Staugaičio raštas Ministrui Pirmininkui, Kaunas, $1920 \mathrm{~m}$. rugsejjo $4 \mathrm{~d}$. Lietuvos centrinis valstybès archyvas (toliau-LCVA), f. 923, ap. 1, b. 100, 1. 279. 
svarsčiusi ši reikalą nusprendè, kad esant nepatogumų išleisti tokị atsišaukimą i Lietuvos rytų šalies gyventojus pačiam Steigiamajam

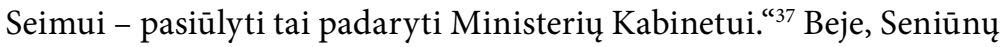
Sueigoje kilo iniciatyva paraginti Ministrų Kabinetą neriboti Lietuvos šaulių sąjungos veiklos ir ịpareigoti Krašto apsaugos ministeriją patvirtinti Šaulių sąjungos įstatus ir kuo skubiau Steigiamajam Seimui svarstyti pateikti Lietuvos šaulių sąjungos įstatymą ${ }^{38}$. Seniūnų sueigos sprendimu Ministrų Kabineto nariai ị paklausimus atsakydavo Seimo posèdžio pradžioje $\mathrm{e}^{39}$.

Šiandienos Lietuvos Respublikos Seime Seniūnų sueigos posėdžiai vyksta nustatytomis savaitès dienomis, prieš plenarinị Seimo posėdị. Seniūnų sueiga pirmaisiais Steigiamojo Seimo metais posėdžiaudavo keletą kartų per savaitę. Vèliau nusistovèjo praktika Seniūnų sueigos posėdžius šaukti šeštadieniais. $1920 \mathrm{~m}$. rugpjūčio $2 \mathrm{~d}$. 34-ame Seimo posėdyje posėdžio pirmininkas pranešè: „[...] kad kitą šeštadienị Seniūnų sueiga nutarè kviesti visų komisijų posėdị pasitart apie atliktas ir dirbamus komisijų darbus. Posėdis ịvyks 9 val. rytą būsimą šeštadienị. “" Dažnai apie būsimą Seniūnų sueigos posèdị būdavo informuojama išvakarèse, baigiantis plenariniam Steigiamojo Seimo posèdžiui: „Rytoj [1920 m. rugsèjo 18 d. - VAR] 9 val. bus Seniūnų sueigos su visom komisijom ir pakomisijom posėdis. Prašom atvykti. “41 Kai kada Seniūnų sueigos posèdžiai būdavo šaukiami tą pačią dieną po plenarinio Seimo posèdžio ${ }^{42}$.

Neatidèliotiniems klausimams spręsti būdavo šaukiami išplèstiniai Seniūnų sueigos ir komisijų posėdžiai, jie kartais vykdavo ple-

37 Ten pat.

38 Steigiamojo Seimo Seniūnų sueigos pirmininko Jono Staugaičio raštas Ministrui Pirmininkui, Kaunas, 1920 m. rugsèjo 27 d. LCVA, f. 923, ap. 1, b. 100, 1. 241.

39 Steigiamojo Seimo sekretoriaus pranešimas Ministrui Pirmininkui, Kaunas, $1920 \mathrm{~m}$. rugsèjo 20 d. LCVA, f. 923, ap. 1, b. 100, 1. 249.

401920 m. rugpjūčio 2 d., 34 posèdis. $S S D$.

$411920 \mathrm{~m}$. rugsèjo $17 \mathrm{~d}$., 42 posèdis. SSD.

421920 m. spalio 1 d., 47 posèdis. SSD. 
narinio Seimo posėdzio pertraukos metu. Antai $1920 \mathrm{~m}$. spalio $6 \mathrm{~d}$. 48-ame Seimo posèdyje buvo pasiūlyta padaryti vienos valandos plenarinio posėdžio pertrauką, o jos metu pakviesti Seniūnų sueigos narius ir Seimo komisijų pirmininkus aptarti tolimesnę posėdžio darbų tvarką. Išplèstinis posedis vyko plenarinių posėdžių salèje ${ }^{43}$. Svarbiausias svarstytas klausimas - Bendrosios teisès komisijos reformavimas. Tos pačios dienos posèdyje Seniūnų sueiga nusprende imtis šiokios tokios komisijų darbo kontrolès ir paprašè, kad „[...] komisijų pirmininkai praneštų apie darbą savo komisijose Prezidiumui raštu. " ${ }^{\text {"4 }} \mathrm{Ti}$ kètina, kad taip buvo bandyta paspartinti isstatymų projektų rengimą ir užtikrinti stabilų Seimo darbą plenariniuose posėdžiuose. Išplèstiniuose Seniūnų sueigos posėdžiuose, rengtuose su Užsienio reikalų komisija, Užsienio reikalų ministerijos atstovai pristatydavo Lietuvos ir Lenkijos ginčo padètị - derybų Briuselyje ir Ženevoje eigą, derybų dèl Hymanso projekto procesą $a^{45}$, Genujos konferencijos rezultatus ${ }^{46}$ ir Lietuvos valstybės poziciją derybose. Taip Lietuvos parlamentas būdavo informuojamas apie tarptautinę Lietuvos valstybès padètį.

\section{Seniūnų sueigoje rengtas Steigiamojo Seimo statutas}

Bene svarbiausias Steigiamojo Seimo Seniūnų sueigos darbas Lietuvos Steigiamojo Seimo statuto redakcija. Steigiamojo Seimo statutas, reglamentuojantis Seimo darbą, buvo priimtas 3-iajame Seimo posèdyje - $1920 \mathrm{~m}$. gegužès $18 \mathrm{~d}$., tačiau $1920 \mathrm{~m}$. liepos $9 \mathrm{~d}$. buvo papildytas $^{47}$, o Steigiamojo Seimo Pirmininkas, einantis Respublikos Prezidento pareigas, ji pasirašè tik $1921 \mathrm{~m}$. rugsèjo 14 d. ir tik $1921 \mathrm{~m}$.

431920 m. spalio 6 d., 48 posèdis. SSD.

44 Ten pat.

${ }^{45} 1921 \mathrm{~m}$. rugsëjo 9 d., 121 posèdis. $S S D$.

${ }^{46} 1922 \mathrm{~m}$. birželio 2 d., 210 posèdis. SSD.

${ }^{47}$ Lietuvos Steigiamojo Seimo statutas. Steigiamojo Seimo priimtas $1920 \mathrm{~m}$. gegužès m. 18 d. ir papildytas 1920 m. liepos m. 9 d., [Kaunas, 1920-1921], spaudinys. 
rugsejjo $28 \mathrm{~d}$. Statuto tekstas buvo paskelbtas „Vyriausybės žiniose“. ${ }^{48}$ Šio statuto pagrindą sudarè pakoreguotas ir papildytas Lietuvos Valstybès Tarybos statutas. Antraisiais Steigiamojo Seimo veiklos metais paaiškejjo šio Statuto trūkumai. Statutui parengti, nuostatoms nugludinti ir suderinti buvo sudaryta atskira Statuto komisija, tačiau 1921 m. gegužès 4 d. Seimas Statuto rengimą pavedè Seniūnų sueigai. Tokị sprendimą lèmé Seimo narių, dirbusių Statuto komisijoje, ittraukimas ị kitų komisijų darbą, kuriose buvo rengiami visam kraštui svarbūs ịstatymai, todèl Seimo statuto rengimas buvo primirštas. 1921 m. gegužès 4 d. 88-ame posėdyje Seniūnų sueigos narys Jonas Makauskas kalbejjo: „[...] manyčiau, kad visus klausimus, surištus su Steigiamojo Seimo statutu, reiktų pavesti Seniūnų sueigai; ji vis tiek paduoda iniciatyvą ir numato, kuriuos punktus reikalinga pakeisti. Jai vistiek reikia svarstyt, tai reikia jai duoti teisés, kad ji galètų referuot ir Steigiamojo Seimo plenume." ${ }^{49}$ Taip statuto rengimo darbas buvo pavestas Seniūnų sueigai, kurios atstovai ne kartą Seimo posèdyje referavo, komentavo arba paaiškindavo įvairias Statuto nuostatas dèl Seimo posėdžių vedimo tvarkos, Seimo posėdžio darbotvarkès sudarymo, Seimo narių ir frakcijų pasisakymų posėdžių metu ir kitais klausimais. Būtent Seniūnų sueigos iniciatyva buvo nuspręsta Seimo posėžio darbotvarkę skelbti ne tik posėdžio pradžioje, bet ir išvakarèse. $1921 \mathrm{~m}$. gegužès $31 \mathrm{~d}$. Steigiamojo Seimo Pirmininkas Aleksandras Stulginskis trumpai išdèstė problemos esmę: „Prie tokio nusistatymo Seniūnų sueiga priejo dèl to, kad darant darbų tvarkos pakeitimą posėžiui pradedant, nei Steigiamojo Seimo nariai, nei Kabinetas [Ministrų Kabinetas - red.] dažnai nežino, kas bus svarstoma; dèl to Seniūnų sueiga, atsižiūrèdama ị tai, ir yra nusistačiusi,

${ }^{48}$ Lietuvos Steigiamojo Seimo statutas. Steigiamojo Seimo priimtas $1920 \mathrm{~m}$. gegužès mèn. 18 d., papildytas liepos mèn. 9 d., einantis Respublikos Prezidento Pareigas Steigiamojo Seimo Pirmininkas Aleksandras Stulginskis ir Ministras Pirmininkas Kazys Grinius pasirašè 1921 m. rugsèjo 14 d. Vyriausybès žinios. 1921, Nr. 71, p. 1-5.

491921 m. gegužès 4 d., 88 posèdis. SSD. 
kad darbų tvarka būtų nustatoma kiekvienam posėdžiui baigiantis. “50 1921 m. birželio 7 d. 101-ame Seimo posèdyje buvo svarstytos Seniūnų Sueigos teiktos Steigiamojo Seimo statuto pataisos, buvo detalizuota îstatymo prièmimo procedūra, konkrečiau - detaliau aptarta balsavimo procedūra, buvo siūloma apriboti pasisakymų laiką, Seniūnų sueiga siūlè leisti kalbèti ne ilgiau nei valandą, nebent išskirtinès aplinkybès reikalautų kalbėti ilgiau ${ }^{51}$.

Apskritai Seniūnų sueiga prisidėdavo formuojant Seimo posėdžių darbotvarkę. ${ }^{52}$ Amžininkai liudijo, kad Seimo statutą puikiai išmanè jo rengejjai, Steigiamojo Seimo Seniūnų sueigos ir Seimo Prezidiumo nariai Aleksandras Stulginskis, Jonas Staugaitis ir Justinas Staugaitis, véliau dar ne kartą èję Lietuvos Respublikos Seimo Pirmininko pareigas.

\section{Seniūnų sueiga prižiūrèjo Seimo komisijų darbą}

Seniūnų sueigai teko prižiūrèti ir kontroliuoti Steigiamojo Seimo komisijų darbą, nes nuo komisijų veiklos kokybės priklausė viso Steigiamojo Seimo darbų sparta - îstatymų projektai turejo būti apsvarstyti Seimo komisijose ir tik po to būdavo įnešami galutiniam svarstymui ir prièmimui Seimo posèdžių saleje. Jei Steigiamojo Seimo kadencijos pradžioje didesnių susikirtimų dèl komisijų veiklos nebuvo, tai bėgant laikui vis labiau ėmė ryškèti takoskyros, buvo suabejota kai kurių komisijų darbo kokybe. Visus nesutarimus ir darbo nesklandumus buvo pavesta išsiaiškinti Seniūnų sueigai. Deja, šaltinių stoka neleidžia rekonstruoti, kaip vyko diskusijos ir kokie motyvai nulemdavo Seniūnų sueigos sprendimus, tačiau sprendžiant iš to, kokie pasiūlymai buvo teikiami Seimo plenumui svarstyti, manytina, kad iš skirtingų frakcijų sudaryta Seniūnų sueiga bandė ieškoti kompromiso ir komisijų veiklos ịgalinimo būdų.

501921 m. gegužès 31 d., 98 posėdis. SSD.

$511921 \mathrm{~m}$. birželio $7 \mathrm{~d}$., 101 posèdis. $S S D$.

$521921 \mathrm{~m}$. vasario $22 \mathrm{~d}$., 65 posèdis. $S S D$. 
Vienas iš ryškesnių kompromiso pavyzdžių galètų būti Bendrosios teisès komisijos reformavimo klausimas. Tai viena iš svarbiausių Steigiamojo Seimo komisijų, todèl, Seniūnų sueigos nuomone, jos sudètị reikèjo pakoreguoti. $1920 \mathrm{~m}$. spalio 6 d. 48-ame Seimo posèdyje buvo pristatyta Seniūnų sueigos pozicija Bendrosios teisès komisiją sudaryti iš 5 Seimo narių ir 2 narių pavaduotojų. O Seniūnų sueigos narys Antanas Tumėnas pasiūle komisiją sudaryti iš 7 narių ir 2 narių pavaduotojų, išimtinai teisininkų. Tačiau svarbiausia, kad Seime buvo pritarta jo pasiūlymui, kad komisijoje: „turètų būt juristai iš visų frakcijų. Bet galètų ịeit net ir asmens ị frakcijas nepriklausą. “53 Šiuo klausimu Steigiamasis Seimas pademonstravo stebėtiną sutarimą, frakcijos ị komisiją delegavo ne tik narius teisininkus, tačiau ir kitus Seimo narius, nepriklausiusius frakcijai. Antai valstiečių liaudininkų bloko vardu buvo pasiūlytas vokiečių atstovas Oskaras Biuchleris ir žydų atstovas Ozeris Finkelšteinas, Lenkų frakcija pasiūlè „kaimyną Požèlą" ${ }^{\text {"54 }}$. Tačiau Vladas Požela kilniai atsisakè pareigų komisijoje, nes buvo pasiūlytas 8-uoju, o komisiją galejo sudaryti tik 7 nariai.

Seniūnų sueiga veikė kaip savitas arbitražas. Kai Seimo Prezidiumas apsvarstęs klausimą negalèdavo priimti galutinio sprendimo, klausimą perduodavo platesniam svarstymui Seniūnų sueigoje. Antai $1921 \mathrm{~m}$. sausi Seimo prezidiumas sulaukẻ Lietuvos geležinkeliečių centro valdybos skundo dèl geležinkeliečių bylos tyrimo pavedimo ministerijos valdininkams - ministerijos tyrëjais geležinkeliečiai nepasitikejo. Šio jautraus klausimo sprendimas buvo pavestas Seniūnų sueigai, ji rekomendavo pritarti geležinkeliečių pozicijai ir sudaryti komisiją iš Steigiamojo Seimo narių šiam klausimui ištirti, kadangi tai buvo didelès apimties ir jautrus tyrimas: „tai yra aukštųjų valdininkų nusikaltimai ir svarbūs atsitikimai" ${ }^{\text {555 }}$.

531920 m. spalio 6 d., 48 posèdis. SSD.

54 Ten pat.

$551921 \mathrm{~m}$. vasario $11 \mathrm{~d}$., 62 posèdis. $S S D$. 
Dar vienas epizodas, liudijantis apie įtampas komisijų darbe, buvo atskirų Seimo narių paklausimas ar interpeliacija dèl vienos iš Steigiamojo Seimo komisijos veiklos. $1922 \mathrm{~m}$. kovo $7 \mathrm{~d}$. 179 posedyje buvo pateiktas paklausimas Steigiamojo Seimo Krašto atstatymo komisijai dèl šios pasyvios veiklos. Dalis Seimo narių manè, kad ši komisija, ìsteigta kartu su kitomis Seimo komisijomis, per visą Steigiamojo Seimo veiklą taip ir neparodė konkrečių rezultatų. Paklausimą pateikę Seimo nariai buvo linkę iškelti ir komisijos likvidavimo klausimą, todèl paklausimą pavadino interpeliacija. Šiuo klausimu Seniūnų sueiga veikè kaip arbitras ir paaiškino, kad Steigiamojo Seimo statute tokios interpeliacijos procedūra nèra numatyta, todèl primygtinai prašè paklausimo nelaikyti interpeliacija ${ }^{56}$.

Bene ryškiausias susidūrimas dèl Seimo komisijų įvyko $1922 \mathrm{~m}$. birželio $16 \mathrm{~d}$. 213-ame Seimo posėdyje. Tai buvo Seniūnų sueigoje priimto pasiūlymo pakeisti Steigiamojo Seimo statutą dèl Seimo komisijų sudarymo proporcijų. Nors Statutas numatė konkretų komisijos narių skaičių ir konkrečią jų sudarymo tvarką, tačiau bėgant kadencijos laikui, išimtinais atvejais, kai kurių komisijų sudètis buvo pakeista, ịtraukiant daugiau Seimo narių, nei numatė statutas. Ypač aštrūs ginčai kilo dèl Švietimo komisijos, kurios 8-as narys buvo Len$\mathrm{kų} \mathrm{frakcijos} \mathrm{atstovas} \mathrm{Adolfas} \mathrm{Grajevskis.} \mathrm{Problema} \mathrm{kilo} \mathrm{po} \mathrm{to,} \mathrm{kai} \mathrm{buvo}$ susivokta, kad komisijose pasikeite frakcijų atstovavimo proporcija. Problema ta, kad, kilus konfliktui, nuo $1921 \mathrm{~m}$. liepos $9 \mathrm{~d}$. né vienas lenkų atstovas Steigiamojo Seimo darbe nebedalyvavo, nors Seimo nario mandatą išsaugojo. Lenkų frakcijos nariai nebuvo atšaukti iš Seimo komisijų ir formaliai toliau ejjo pareigas jose. Tuo tarpu Krikščionių demokratų blokas nejučia vietoje Lenkų frakcijos atstovo paskyrè pavaduotoją iš savo narių. Tai papiktino kitų frakcijų atstovus. Ginčai pasidarè tokie, kad buvo apsunkintas komisijų darbas - dalis Seimo narių atsisakydavo dalyvauti komisijos posėdžiuose - komisijos

${ }_{56} 1922$ m. kovo 7 d., 179 posèdis. SSD. 
nesurinkdavo kvorumo ${ }^{57}$, negalėdavo sudaryti komisijų prezidiumo, neatsirasdavo komisijos narių įstatymų referentų pristatyti įstatymui Seimo posèdžių saleje. Todèl Seniūnų sueigai buvo pavesta iš naujo peržiūrèti komisijų sudarymo tvarką ir pasiūlyti atitinkamą Steigiamojo Seimo statuto redakciją ${ }^{58}$.

\section{Seniūnų sueiga sprendè Steigiamojo Seimo posèdžių pertraukos klausimą}

Steigiamasis Seimas sprende ir Seimo atostogų klausimą. Steigiamojo Seimo pertraukos, arba Seimo „trumpų atostogų“ klausimas, buvo pavestas būtent Seniūnų sueigai. Seniūnų sueigos pirmininkas Jonas Staugaitis $1920 \mathrm{~m}$. rugpjūčio $11 \mathrm{~d}$. pabrèžè: „Seniūnų sueiga pripažino reikalingu ir galimu padaryt Steigiamojo Seimo posėdžių pertrauką. Pripažino reikalingu todèl, kad Steigiamojo Seimo nariai, dirbusieji intensingai plenume, frakcijose ir komisijose, po 10-12 valandų kasdien, jaučias nuvargę, ir todèl būtų reikalinga jiem padaryt nors trumpą posèdžių pertrauką. Pertrauką daryt pripažino galimu, nes svarbesnieji klausimai tapo priimti, konstitucijos gi ir žemės reformos klausimai gali būt parengti tik po kelių mẻnesių, visi kiti klausimai ir įstatymų sumanymai pripažinti neskubotais ir todèl negali būt kliūtimi padaryt mažą pertrauką. Seniūnų sueigos nutarimu galima padaryt pertrauką plenumo 4 savaitèm, o komisijų darbam - 2 savaitèm. ${ }^{\text {"59 }}$ Beje, šiam nutarimui Seniūnų sueigoje buvo pritarta 14 balsavus „už“ nutarimą ir 1 - „prieš“ ${ }^{60}$. Steigiamojo Seimo nariai teisininkai, medikai, pedagogai, ùkininkai rado vis kitų argumentų, kodèl būtina pertrauka, kodèl ji būtų reikalinga ilgesnè, ką būtina atlikti iki Seimui trumpam išsiskirstant. Galiausiai tą trumpą pertrauką tarp posẻdžių

571922 m. rugpjūčio 17 d., 242 posèdis. $S S D$.

$581922 \mathrm{~m}$. birželio $16 \mathrm{~d}$., 213 posèdis. SSD.

$591920 \mathrm{~m}$. rugpjūčio $11 \mathrm{~d}$., 38 posèdis. $S S D$.

60 Ten pat. 
buvo siūloma išnaudoti išsiaiškinti gyventojų nuotaikoms provincijoje, sužinoti jų požiūrị, ką pirmiausia turètų nuveikti Seimas. Taigi 1920 metais Steigiamasis Seimas vieną mènesị, nuo rugpjūčio 15 d. iki rugsejjo 15 d., atostogavo ${ }^{61}$. Iš esmès tai reiškè, kad mènesị nevyko plenariniai Steigiamojo Seimo posėdžiai ir tik dvi savaites nevyko komisijų posèdžiai, tuo metu dirbo Seniūnų sueiga, kurios rankose buvo sutelkta svarbi Seimo galia. $1920 \mathrm{~m}$. rugpjūtị atskiru isstatymu ${ }^{62}$ Seimo plenarinių posėdžių pertraukos metu Steigiamojo Seimo Seniūnų sueigai buvo pavesta ìstatymų vykdymo priežiūra ${ }^{63}$. Seniūnų sueigos pirmininkas Jonas Staugaitis dar 1920 m. rugpjūčio 11 d. Steigiamojo Seimo posėdyje kalbėdamas apie šios funkcijos pavedimą Seniūnų sueigai sakè, kad, Seimui išsiskirsčius, nors mažesnė jo dalis turi likti dirbti: „Tokiu svarbiu momentu visiem išsiskirstyti, išvažiuoti; reikètų kam nors pasilikti. Nors reikalui esant Seimą būtų galima ị tris dienas sušaukt, bet vis tik turètų čia vietoj pasilikt kokia nors komisija, kuri galètų tą sušaukimo darbą atlikt. Tą galès atlikt seniūnų sueiga, kuri be to turès dar prižiūrèti ịstatymų vykinimą pertraukos metu. Konstitucijos komisija paruošè ir įnešè įstatymą, kuriuo nurodomos seniūnų sueigos teisès pertraukos metu. “64 Šią poziciją parèmė Steigiamojo Seimo Konstitucijos komisija, svarsčiusi klausimą, kas pertraukos metu turètų užimti Steigiamojo Seimo vietą, ji nutarè: „[...] pavest Seniūnų sueigai prižiūrèt vieną darbų dalị, būtent įstatymų vykinimą. Todèl tai pertraukos metu vykinimas ịstatymų ir paliekama Seniūnų sueigos priežiūrai." ${ }^{65}$, Konstitucijos komisijos vardu kalbejjo ịstatymo projektą plenarinio posėdžio metu pristatęs Antanas Tumènas. Po diskusijų tolimesnis šio lakoniško įstatymo svarstymas buvo perduotas Teisių

61 Ten pat.

62 Ten pat.

${ }^{63}$ İstatymas dèl Steigiamojo Seimo seniūnų sueigos teisès prižiūrèti ịstatymo vykdymo, Kaunas, 1920 m. rugpjūčio 14 d. Vyriausybès žinios. 1920 m. rugpjūčio 18 d., Nr. 45-457.

${ }^{64} 1920$ m. rugpjūčio 11 d., 38 posèdis. $S S D$.

65 Ten pat. 
komisijai, o galutinis balsavimas įvyko jau kitame 39-ame Steigiamojo Seimo posėdyje - $1920 \mathrm{~m}$. rugpjūčio $13 \mathrm{~d}$. Tos dienos posédyje buvo sutarta, kad pertraukos metu Seimo nariai per Seniūnų sueigą galès teikti paklausimus Ministrų Kabinetui (valdžios atstovai tik tuomet privalèdavo atsakyti ì paklausimus, kai jie būdavo pateikiami Seime), o Seimo narys Mykolas Sleževičius dar paaiškino: „Valdžios akyse ji [Seniūnų sueiga - red.] bus teisèta komisija ne tik paklausimam, bet ji bus toji teisèta įstaiga, $\mathfrak{i}$ kurią valdžia gali kreiptis kiekvienu svarbiausiu atsitikimu, kad išgirdus nuomonę, kuri atvaizduoja Seimą “" ${ }^{\text {"66 }}$ Mykolui Sleževičiui pasiūlius Seniūnų sueigai buvo apribota interpeliacijos teisè, t. y. Seniūnų sueiga pertraukos metu negalèjo atstatydinti ministrų. Jau kitą dieną, 1920 m. rugpjūčio 14 d., İstatymą dèl Steigiamojo Seimo seniūnų sueigos teisès prižiūrèti įstatymo vykdymo pasirašè Respublikos Prezidento pareigas einantis Steigiamojo Seimo Pirmininkas Aleksandras Stulginskis ir Ministras Pirmininkas Kazys Grinius ${ }^{67}$.

Deja, kai susidarè ypatingos krašto gynimo sąlygos ir Steigiamojo Seimo nariai èmé svarstyti galimybę neberengti Seimo posėdžių, bet imtis organizuoti valstybės gynimą ir ginklu ginti valstybę, Seniūnų sueigai nebuvo patikèta atstovauti Steigiamajam Seimui. Nors tokių siūlymų buvo - šią idèją remdamasis prieš keletą mėnesiu buvusiu precedentu rèmé socialdemokratų atstovas Kazimieras Venclauskis ${ }^{68}$. Vykstant atviroms kovoms su Lenkijos kariuomene, baiminantis dèl Lietuvos valstybès išlikimo, Steigiamojo Seimo nariai svarsté, kuri jų veikla galètų būti naudingiausia valstybei. Bandant sureguliuoti konfliktą, 1920 m. spalio 7 d. buvo sudaryta Suvalkų sutartis, tačiau netrukus situacija dar labiau komplikavosi, kai 1920 m. spalio 9 d. Lenkijos generolo Liucijano Želigovskio vadovaujami kariai, sulaužy-

${ }_{66} 1920$ m. rugpjūčio 13 d., 39 posèdis. SSD.

${ }^{67}$ İstatymas dẻl Steigiamojo Seimo seniūnų sueigos teisès prižiūrèti įstatymo vykdymo, Kaunas, 1920 m. rugpjūčio 14 d. Vyriausybės žinios. 1920 m. rugpjūčio 18 d., Nr. 45-457.

681920 m. spalio 22 d., 54 posėdis. SSD. 
dami sutartị, užèmé Vilnių, o po dviejų dienų, spalio 12-ąją, paskelbė Vidurio Lietuvos Respubliką su sostine Vilniuje. Jau 1920 m. spalio 9 d. Seime vyko išplèstinis Seimo seniūnų sueigos ir Seimo Užsienio reikalų, Krašto apsaugos bei Finansų ir biudžeto komisijų posėdis, kuriame dalyvavo Ministrų Kabineto ir Lietuvos gynimo komiteto atstovai. Šio posėdžio tikslas buvo apsvarstyti Lietuvos gynimo klausimus ir bendradarbiaujant su atitinkamomis ministerijomis įvertinti pasipriešinimo galimybes ${ }^{69}$. Padètis sparčiai keitèsi, vos prieš keletą dienų nuo dalyvavimo Seimo posėdžiuose atleidę keletą kolegų kariškių, kurie grịžo ị Lietuvos kariuomenę, Steigiamojo Seimo nariai netrukus èmé svarstyti Mažojo Seimo ịstatymo projektą. Idejja sukurti mažesnị, optimalesnị valdymo institutą buvo pristatyta $1920 \mathrm{~m}$. spalio 20-21 dienomis vykusiuose Seimo seniūnų sueigos, Ministrų Kabineto, Seimo frakcijų ir kai kurių Seimo komisijų atstovų pasitarimuose $^{70}$. Šių pasitarimų metu ir buvo nuspręsta kritiniu valstybei metu sudaryti mažesni valdymo organą, netrukus buvo parengtas Mažojo Seimo sudarymo įstatymo projektas.

1920 m. spalio 22 d. 54-ame Seimo posėdyje svarstant Mažojo Seimo sudarymo įstatymą buvęs Seniūnų sueigos narys Vladas Lašas, paremdamas Mažojo Seimo idèją, kalbejo: „Aš pasakysiu, kad Seniūnų sueiga yra dar didesnis aparatas. O Mažasis Seimas bus mažesnis aparatas ir taip pat išeis iš Steigiamojo Seimo. “71 Mažajam Seimui, kuris atvaizdavo partinę Steigiamojo Seimo sudètị, buvo suteikta daugiau igaliojimų - būtent leisti ịstatymus ir tvirtinti kreditus, nors ir būdamas mažesnès sudèties, tačiau jis atstovavo Steigiamajam Seimui. Tuo tarpu, kaip pabrèžė krikščionių demokratų atstovas Vytautas Bičiūnas, „Seniūnų Sueiga yra organinė pačio St. Seimo dalis. "72 Dauguma Seimo narių parèmè Mažojo Seimo, sudaryto vos

${ }^{69}$ Steigiamasis Seimas ir nauja lenkų okupacija. Lietuva. 1920, spalio 14, p. 1.

${ }^{70}$ Iš Steigiamojo Seimo. Lietuva. 1920, spalio 22, p. 2.

$711920 \mathrm{~m}$. spalio 22 d., 54 posėdis. SSD.

${ }^{72}$ Ten pat. 
iš 7 Seimo narių, idejją, buvo manančių, kad iš 19 Seimo narių sudaryta Seniūnų sueiga nebus greita priimant sprendimus, o kai kurie Seimo nariai įžvelgè pavojų, kad suteikus daugiau galių Seniūnų sueigai ji gali pretenduoti tapti antraisiais parlamento rūmais ${ }^{73}$. Prièmus Mažojo Seimo įstatymą buvo nuspręsta kurị laiką nebešaukti Seimo posèdžių, tačiau darbą sutelkti svarbiausiose Steigiamojo Seimo komisijose, tokiomis buvo pripažintos Žemès reformos, Konstitucijos, Krašto apsaugos ir Užsienio reikalų komisijos. Parlamentas ir toliau liko svarbiausia institucija valstybejje, jam buvo atskaitingas Ministrų Kabinetas ir Valstybės kontrolè. Visi Mažojo Seimo nariai yra buvę ir Steigiamojo Seimo Seniūnų sueigos nariais: Aleksandras Stulginskis, Mykolas Krupavičius, Antanas Tumėnas, Mykolas Sleževičius, Vladas Lašas, Kazimieras Venclauskis, Naftalis Fridmanas (iš Mažojo Seimo narių kandidatų (pavaduotojų) tik Steponas Kairys nèra buvęs Steigiamojo Seimo seniūnų sueigos nariu, kiti Mažojo Seimo nariai kandidatai Ladas Natkevičius, Jonas Kriščiūnas, Juozas Vailokaitis, Eliziejus Draugelis, Maksas Soloveičikas).

\section{Seniūnų sueiga rekomenduodavo Seimo darbą plenariniuose posèdžiuose: posèdžių periodiškumą ir trukmę}

Steigiamojo Seimo kadencijos metu plenarinių Seimo posėdžių periodiškumas keisdavosi priklausomai nuo to, kiek daug istatymų projektų būdavo parengiama svarstyti. Pirmieji Steigiamojo Seimo posėdžiai vykdavo skirtingu laiku, nesilaikant griežto periodiškumo. Seimo plenarinių posėdžių laiko nustatymas buvo pavestas Seniūnų sueigai.

Dar 1920 m. gegužès pabaigoje, po intensyvių pirmųjų Steigiamojo Seimo darbo savaičių, Seniūnų sueiga pasiūlè sumažinti Seimo po-

${ }^{73}$ Ten pat. 
sẻdžių skaičių ir labiau susitelkti konstruktyviam darbui komisijose. Pirmieji Steigiamojo Seimo plenariniai posėdžiai vykdavo skirtingu laiku, neretai prasidedavo tik 18 ar 19 val. ir užsitęsdavo iki vidurnakčio. 1920 m. gegužès 28 d. posẻdyje Seniūnų Sueigos pirmininkas Jonas Staugaitis pristate problemos esmę: „[...] Seniūnų Sueigos nutarta, kad perdaug skrupulingai dirbam, kas atsiliepia i Seimo ir komisijų darbo sveikatą, todel nutarta sumažint posėdžių skaičių. "74 Seimas pritarè šiam pasiūlymui ir apsisprendè posėdžiauti tris dienas per savaitę: pirmadieniais, trečiadieniais ir penktadieniais nuo 9 val. iki 14 val. ${ }^{75}$ Idomu, kad net pačioje Seniūnų Sueigoje būta pasiūlymų plenarinius Seimo posėdžius rengti vakarais: „kad galètų atsilankyt publika, ministeriai, valdininkai, kurie dieną atsilankyt negali. " ${ }^{76}$ Iš tiesų, tuo metu buvo kilęs didžiulis visuomenès susidomèjimas ilgai laukto Steigiamojo Seimo darbu. Pagaliau visuomenẻ laukẻ konkrečių žingsnių sprendžiant opius valstybės klausimus, taip pat igyvendinant rinkimuose pažadètas reformas. Socialdemokratų frakcija pritarė plenarinių posėdžių organizavimui vakarais, paremdama mintị, kad posèdžio eigą laisvai galintys stebėti piliečiai galètų susidaryti palankesnę nuomonę apie Seimą ir tai, ką jis veikia. Buvo manoma, kad žiniasklaidoje Steigiamojo Seimo darbas nušviečiamas nepakankamai, o kartais tendencingai ${ }^{77}$. Be to, reikejjo ịvertinti ir tą aplinkybę, kad Kauno miesto teatre (dabar - Kauno valstybinis muzikinis teatras), kuriame tuo metu vyko Steigiamojo Seimo posėdžiai, galejo patogiai tilpti ir daugiau pašalinių posėdžių stebėtojų. Tačiau jau nuo $1920 \mathrm{~m}$. birželio vidurio Steigiamasis Seimas persikèlè ị nuolatinius rūmus, buvusị Gimnazijos pastatą (dabar - Kauno Maironio universitetinè gimnazija), o ten posédžio stebėtojams buvo numatyta visai nedaug vietos. Seimo posèdžių laiko derinimą prie publikos poreikių sukri-

\footnotetext{
741920 m. gegužès 28 d., 8 posèdis. $S S D$.

75 Ten pat.

76 Ten pat.

77 Ten pat.
} 
tikavo krikščionių demokratų atstovas Vytautas Bičiūnas, pabrèžęs, kad Steigiamojo Seimo nariai susirinko ne publikos linksminti ${ }^{78}$. Nepaisant to, anuomet Seimo posėdžiai sutraukdavo pašalinių stebėtojų, kuriuos traukdavo aštrūs politinių oponentų apsižodžiavimai. Seniūnų Sueigos narys krikščionis demokratas Kazimieras Ambrozaitis paremdamas Seniūnų sueigos siūlymą įvesti trijų plenarinių posėdžių per savaitę normą paaiškino Seniūnų sueigoje svarstytus motyvus: taip bus garantuotas produktyvesnis Seimo darbas, mat svarbiausios diskusijos turètų vykti komisijose, o ị plenarinių posėdžių salę ịstatymų projektai turètų atkeliauti radus kompromisinį variantą, tad posédyje neturètų kilti ginčų dẻl smulkmenų. Na ir rytą î posẻdị susirinkę Seimo nariai turètų būtų produktyvesni: „ryte šviesiu protu ir budriu organizmu geriau dirbs ${ }^{\text {“79 }}$, nei ị posèdị susirinkę vakare, jau po darbo komisijose. Steigiamajam Seimui persikrausčius dirbti ị nuolatinius Seimo rūmus, Seniūnų sueiga inicijavo darbo vietų, tai yra kabinetų, paskirstymą Seimo komisijų posėdžiams. Be to, Seniūnų sueigos siūlymu frakcijų posėdžių laikas buvo paskirtas Seimo plenarinių posédžių dienomis po pietų - pirmadieniais, trečiadieniais ir penktadieniais $^{80}$.

Tačiau tokio plenarinių Seimo posėdžių periodiškumo nepavyko išlaikyti. Po keturių mėnesių, 1920 m. rugsèjo 20 d., 43-iame Seimo posėdyje Seniūnų sueigos siūlymu plenarinių Seimo posėdžių skaičius buvo sumažintas iki dviejų per savaitę: „Seniūnų sueiga yra nutarusi, kol komisijos neparengs daugiau medžiagos plenumui svarstyt, laikinai daryt plenumo posėdžius du kart per savaitę, būtent: pirmadienį ir penktadienị. " ${ }^{\text {"81 }}$ Seniūnų sueigoje šis sprendimas buvo priimtas $1920 \mathrm{~m}$. rugsẻjo $18 \mathrm{~d}$. Tą dieną vyko bendras Seniūnų sueigos ir komisijų bei subkomisijų posėdis, surengtas praejus vos porai dienų po to, kai po

\footnotetext{
78 Ten pat.

79 Ten pat.

${ }^{80} 1920$ m. birželio 7 d., 12 posèdis. SSD.

811920 m. rugsèjo 20 d., 43 posèdis. SSD.
} 
mènesio pertraukos Steigiamasis Seimas vèl susirinko ỉ plenarinių posèdžių salę. Bendrame susirinkime buvo bandoma išsiaiškinti, kurie îstatymų projektai yra parengti, kokiame rengimo etape yra pagrindiniai ìstatymai ir kaip atsižvelgiant ị tai būtų galima formuoti Steigiamojo Seimo plenarinių posėdžių darbotvarkę, kam turètų būti skiriamas prioritetas ${ }^{82}$. Paaiškejjus, kad Seimo komisijoje darbas nèra toks spartus, kaip buvo tikètasi, teko sumažinti plenarinių Seimo posèdžių skaičių. O $1921 \mathrm{~m}$. sausio 25 d. 57-ame Steigiamojo Seimo posèdyje buvo pritarta Seniūnų sueigos sprendimui plenarinius posėdžius rengti antradieniais ir penktadieniais nuo 10 val. iki 14.30 val. ${ }^{83}$ Reikètu atminti, kad tai buvo laikas, kai po Mažojo Seimo veiklos Steigiamasis Seimas vèl susirinko darbui visa apimtimi. Seimo darbo pertraukimas turẻdavo pasekmių. $1921 \mathrm{~m}$. pavasarị vèl buvo grịžta prie trijų Seimo posẻdžių per savaitę. Seniūnų sueigos manymu, visi jie turèjo būti skirti Žemès reformos įstatymui svarstyti ${ }^{84}$. $1921 \mathrm{~m}$. liepos $9 \mathrm{~d}$. buvo apsispręsta ir vèl daryti Seimo plenarinių posėdžių pertrauką - iki liepos $30 \mathrm{~d}$. išsiskirstyti savotiškoms atostogoms ${ }^{85}$. Po pertraukos susirinkęs Steigiamasis Seimas ir vèl apsisprendè posėdžiauti du kartus per savaitę ${ }^{86}$. Tačiau kai tik susikaupdavo daugiau ịstatymų projektų Seimas, Seniūnų sueigos siūlymu, vèl grịždavo prie trijų posėdžių per savaitę - du posėdžiai turèjo būti skiriami pamatiniams klausimams spręsti, o vienas - einamiesiems reikalams aptarti ir spręsti ${ }^{87}$.

Nors buvo nustatytas labai konkretus Seimo posėdzių trukmès laikas, šios tvarkos ne visada laikytasi, neretai plenariniai posėdžiai užsitęsdavo, vykdavo visą dieną iki vėlyvos nakties, o kartais prasidejję rytą baigdavosi po vidurnakčio, kitos dienos rytą. Pavyzdžiui, du paskutiniai Steigiamojo Seimo posėdžiai: priešpaskutinis 256-as

${ }_{82} 1920 \mathrm{~m}$. rugsėjo 17 d., 42 posèdis. SSD.

${ }^{83} 1921 \mathrm{~m}$. sausio 25 d., 57 posèdis. $S S D$.

${ }^{84} 1921 \mathrm{~m}$. birželio 21 d., 107 posèdis. SSD.

${ }^{85} 1921 \mathrm{~m}$. liepos 9 d., 117 posèdis. SSD.

${ }^{86} 1921 \mathrm{~m}$. rugpjūčio 30 d., 118 posèdis. $S S D$.

${ }^{87} 1922 \mathrm{~m}$. sausio 17 d., 159 posèdis. SSD. 
prasidejo 1922 m. spalio 6 d. 10 val. 13 min., baigèsi - 14 val. 50 min., o paskutinis 257-as Steigiamojo Seimo posėdis prasidejo tos pačios dienos vakarę - $18 \mathrm{val} .30 \mathrm{~min}$. ir trukęs kone visą naktị baigèsi 1922 m. spalio 7 d. paryčiais - 3 val.

\section{Seniūnų sueiga svarstė nelietuvių kalbos vartojimo Seimo posèdžių metu klausimą}

Dar vienas įdomus klausimas, svarstytas Seniūnų sueigoje, - Seimo posėdžio kalbos klausimas, tai yra, kuriomis kalbomis leidžiama kalbèti Seimo plenarinių posèdžių salejje. Šis klausimas labai aštriai iškilo 1920 m. birželio 16 d. 16-ame Steigiamojo Seimo posèdyje, svarstant interpeliacijos dèl svetimšalių išsiuntimo iš Lietuvos klausimą. Diskusijoje žodžio paprašęs Žydų frakcijos atstovas Maksas Soloveičikas prašè leisti kalbèti ne lietuvių kalba. Posėdžio pirmininkas informavo Seimo narius: „St. Seimo statutas nepažymi, kuriomis kalbomis reikia kalbėti. Atstovas Soloveičikas prašo leisti jam kalbėti rusų kalba. Siūlau išsitarti dèl vartojimo nevietos kalbų plenumo posėdžiuose." ${ }^{\text {"88 }}$ Žydų atstovai Seime dažniausiai kalbėdavo jidiš kalba, tačiau manydami, kad šios kalbos gali nesuprasti kiti parlamentarai, bandè kalbėti rusų kalba, manydami, kad ją turètų suprasti dauguma. Seniūnų sueigos narys Kazimieras Jokantas priminė, kad šis klausimas jau buvo svarstytas Seniūnų sueigoje: „[...] buvo nutarta, kad Seime leidžiama kalbèti vietos kalba, arba kas silpnai moka kalbos paskaityti iš raš-

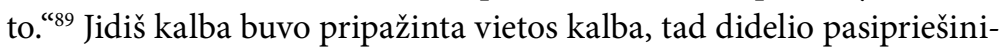
mo dèl kalbejjimo ja nebuvo, didžiausia diskusija kilo dèl rusų kalbos vartojimo Lietuvos Respublikos Seimo posėdžiuose. 1920 m. birželio 16 d. Seimo posėdžio metu Krikščionių demokratų bloko narys Antanas Tumėnas, pasisakydamas prieš rusų kalbos vartojimą Seime, argumentavo: „Žydų kalba - vietos kalba, ir ją suprasti aš galiu, o rusų

$\overline{88} 1920 \mathrm{~m}$. birželio 16 d., 16 posèdis. SSD.

89 Ten pat. 
kalbos suprasti aš neprivalau. Vietos kalba teismuose yra pripažinta, o rusų kalba nepripažinta, todèl jos ir negalima vartoti. Atstovui Soloveičikui gal rodos, kad mes geriau rusų kalbą suprasime, bet kada ittaria, kad mes ją turim suprasti Seime, tai be prasmès. ${ }^{\text {"90 }}$ Buvo siūlyta leisti kalbèti Seimo nariams savo kalbomis, jas verčiant į lietuvių kalbą, tačiau greitai šios minties atsisakyta, nes ėmus versti žydų, lenkų ir vokiečių atstovų pasisakymus ị lietuvių kalbą labai išsitęstų posẻdžių laikas. Beje, ir Steigiamojo Seimo posėdžių stenogramos liudija, kokia opi buvo ši problema - žydų tautybès parlamentarų pasisakymų, jei jie kalbejjo jidiš kalba - stenogramose nèra ${ }^{91}$ dèl paprastos priežasties šios kalbos nemokejjo stenografininkai. Galiausiai, klausimo sprendimas dèl to, kokiomis kalbomis galima kalbèti Seimo posėdžio metu, buvo perduotas Seniūnų sueigai ${ }^{92}$. Na, o Maksas Soloveičikas, kadencijos pradžioje per posėďius kalbejjęs jidiš ir rusų kalbomis, vėliau prakalbo lietuviškai ir sulaukè kitų Seimo narių sveikinimų ir palaikymo.

\section{Steigiamojo Seimo nariams buvo svarbi patikima ir aktuali informacija - Seniūnų sueiga inicijavo Seimo bibliotekos steigimą}

Seniūnų sueiga inicijavo svarbaus Steigiamojo Seimo raštinès padalinio - Bibliotekos - steigimą. Šiandien internetu pasiekiama informacija Steigiamojo Seimo nariams būtų buvusi neịsivaizduojama fantastika. Seimo nariai vertino patikimos, analitinès informacijos svarbą, todèl Seniūnų sueiga, spręsdama Seimo narių aprūpinimo aktualia informacija klausimą, jau pirmuosiuose savo posėdžiuose iškèlè Seimo bibliotekos klausimą. Apie poreikį turèti Biblioteką pirmą kartą Seimo posėdyje buvo balsuota dar $1920 \mathrm{~m}$. gegužès $31 \mathrm{~d} .^{93} 9$-ame

\footnotetext{
90 Ten pat.

91 Pavyzdžiui, likęs įrašas: „Soloveičikas (ž). (Kalba žydiškai dėl tvarkos)“, žr.: Ten pat.

92 Ten pat.

931920 m. gegužès 31 d., 9 posèdis. $S S D$.
} 
Seimo posėdyje, o jau kitame - 10-ame posedyje, vykusiame $1920 \mathrm{~m}$. birželio 2 d., Seniūnų sueigos pirmininkas Jonas Staugaitis kalbejo: „Tas klausimas buvo iškeltas Seniūnų sueigoj ir pripažinta, kad biblioteka būtinai reikalinga ir kad ją reikia kuo veikiau organizuot. Seniūnų sueiga rado tiksliausia išrinkt komisiją iš visų frakcijų atstovų, kuri priiminès reikiamų knygų sąrašus. Visos komisijos, kurios reikalingos knygų, privalo kreiptis ị tą komisiją. " sudaryta 7 narių Bibliotekos komisija, kurios nariais tapo Krikščionių demokratų bloko atstovai Vladas Jurgutis, Magdalena Galdikienè ir Vincentas Mieleška, Valstiečių liaudininkų bloko atstovai Antanas Tamošaitis ir Kazys Kupčiūnas, socialdemokratų atstovas Antanas Purẻnas, Žydų frakcijos atstovas Nachmanas Rachmilevičius ${ }^{95}$. Bègant kadencijos laikui Bibliotekos komisijos narių sudètis kito.

Taip buvo sudaromi Seimo bibliotekos prenumeruojamų periodinių leidinių, žinynų, enciklopedijų, mokslinių žurnalų, leistų Lietuvoje ir užsienyje, sąrašai. Steigiamojo Seimo nariai naudojosi ir centrinio valstybès knygyno, kuriam vadovavo prof. Eduardas Volteris, paslaugomis. Kurị laiką centrinis knygynas glaudèsi Seimo rūmuose ${ }^{96}$. Svarstant Steigiamojo Seimo sąmatą Vladas Jurgutis pabrèžè: „[...] tikrai paskutiniu metu Steigiamojo Seimo nariai labai daug naudojasi knygynu. “97 Tos pačios dienos - 1920 m. rugpjūčio $10 \mathrm{~d}$. 37-ame posėdyje buvo pritarta atskiros Steigiamojo Seimo bibliotekos įrengimui ir išlaikymui, iki metų pabaigos skirti 47000 auksinų, tai yra, knygoms įsigyti buvo skirta 37000 auksinų, o laikraščių ir dienraščių prenumeratai - 10000 auksinų ${ }^{98}$. Beje, Seniūnų sueigos iniciatyva buvo nuspręsta Lietuvos valstybės institucijoms išplatinti Steigiamojo

${ }^{94} 1920$ m. birželio 2 d., 10 posėdis. SSD.

${ }^{95}$ Ten pat.

${ }^{96}$ Raškauskas, K. Eduardas Volteris ir Lietuvos nacionalinès bibliotekos pradžia, bernardinai.lt, https://www.bernardinai.lt/2016-10-22-eduardas-volteris-ir-lietuvos-nacionalines-bibliotekos-pradzia/

${ }^{97} 1920$ m. rugpjūčio 10 d., 37 posèdis. $S S D$.

${ }^{98}$ Ten pat. 
Seimo raštinès rengtą leidinị "Steigiamojo Seimo darbai“, kuriame buvo spausdinamos Seimo posèdžių stenogramos ${ }^{99}$. Po kelerių metų Lietuvos Respublikos Seime viešèjęs Latvijos Respublikos Seimo Pirmininkas interviu Latvijos žurnalistams užsiminè apie apsilankymą Lietuvos parlamento bibliotekoje ir skaitykloje $\mathrm{e}^{100}$.

\section{Seniūnų sueiga sprendẻ darbo vietų Seimo nariams ịrengimą ir Seimo narių atlyginimo klausimą}

Steigiamajam Seimui persikèlus ị buvusius Gimnazijos rūmus, kurie tapo nuolatine Lietuvos Respublikos Seimo buveine iki pat $1927 \mathrm{~m}$. balandžio 12 d., kai Lietuvos Respublikos Prezidentas paleido Trečiąji Seimą (1926-1927 m.), kilo klausimas dèl Seimo narių darbo sąlygų. Jos tikrai nebuvo pačios patogiausios. Ankštoje saleje turèjo tilpti 112 Steigiamojo Seimo narių, Ministrų Kabineto atstovai, turejo būti numatyta vieta užsienio šalių diplomatams ir kitiems svečiams, kviečiamiems dalyvauti posėdyje. O kur dar Seimo raštinès tarnautojai, aptarnaujantys Seimo narius posedžio metu, bei spaudos atstovai, stebintys posėdžius ir vèliau juos aprašantys spaudos puslapiuose, taip pat ir smalsuoliai iš gatvès, galintys užeiti ir stebèti Seimo posėdi. Steigiamojo Seimo Seniūnų sueigoje kilo sumanymas įrengti patogesnes darbo vietas Seimo nariams, tačiau pasiūlymas buvo pateiktas ne laiku, tuo metu dar buvo gyva viltis persikelti ị sostinę Vilnių, tad niekas nemanė Kaune užsibūti net du dešimtmečius.

Nemenką apsižodžiavimą Seimo posėdyje išprovokavo Seniūnų sueigos pasiūlymas Seimo plenarinių posėdžių saleje ịrengti patogesnes darbo vietas Steigiamojo Seimo nariams. Galimybė atsirado, kai buvo persvarstoma Steigiamojo Seimo išlaidų sąmata. Steigiamajam Seimui pradejus darbą išlaidos jo veiklai nebuvo konkrečiai

99 Steigiamojo Seimo raštinès direktoriaus raštas Ministrų Kabineto reikalų vedejui, Kaunas, 1920 m. liepos 20 d. LCVA, f. 923, ap. 1, b. 100, 1. 307.

${ }^{100}$ Saeimas priekšsēdētāja viesošanās Lietuvā. Latvijas Kareivis. 10.01.1925, Nr. 7. 
nustatytos, todèl 1920 m. rugpjūčio 10 d. 37-ame posėdyje Seimas balsavo dèl Steigiamojo Seimo išlaidų sąmatos prièmimo. Seniūnų sueiga pasiūlè Seimo nariams ịrengti patogesnes kẻdes, kurioms planuota išleisti 180000 auksinų $^{101}$. Tuo metu, kai buvo svarstoma Steigiamojo Seimo išlaidų sąmata, niekas nebuvo tikras, kiek ilgai Seimas ir kitos valstybès institucijos dirbs Kaune, mat buvo tikimasi, susiklosčius palankiai geopolitinei situacijai, dar tais pačiais metais grịžti i Lietuvos sostinę Vilnių, o persikeliant ị kitą pastatą - naujai ịsigytos kẻdès naujoje saleje gali visai netikti. Todèl Seimo nariai gana kritiškai pažiūrèjo ị išlaidas, kurias sudarẻ buvusių gimnazijos rūmų pritaikymas Seimo poreikiams. Pasirodo, Seimo narių darbo vietų klausimas Seniūnų sueigoje buvo svarstytas dar 1920 m. birželio 13 d., tąsyk buvo nuspręsta: „[...] padaryt Steigiamojo Seimo nariam patogesnes sẻdynes $^{\text {"102, }} 1920 \mathrm{~m}$. liepos $3 \mathrm{~d}$. buvo pristatyta ir išlaidų sąmata ${ }^{103}$. Seniūnų sueigos pirmininkas Jonas Staugaitis motyvavo: „Sèdynès reikalingos, kadangi esamose sėdynèse atstovam labai nepatogu sèdèt, nèra kur pasidèt portfelio ir ant ko rašyt, nariai vos tegali išsèdèt iki posėdžio pabaigos. [...] Šios kèdès, kurios čia yra, bus reikalingos frakcijom. Be to, jos net ne mūsų, o Matininkų kursų, kurie kiekvieną dieną gali jų iš mūsų pareikalaut. Mes galime liktis visai be kẻdžių. Be to, dar vienas argumentas, kad tos kèdès dirbtinos, tai kad vietos darbininkai turètų uždarbio." ${ }^{104}$ Taip Jonas Staugaitis bandè ị išlaidų sąmatą grąžinti Finansų ir biudžeto komisijos išbrauktas išlaidas. Šios komisijos narys Kipras Bielinis prasitarè, kad buvo parengti net kèdžių planai: „Jos turi būt su tam tikrais piupitrais.“105, ir prieštaraudamas išlaidų didinimui, pabrèžè, kad Seimas posėdžiauja tik tris kartus per savaitę, tad kèdžių keitimo klausimas visai nèra aktualus. Seniūnų

${ }^{101} 1920$ m. rugpjūčio 10 d., 37 posèdis. $S S D$.

${ }^{102}$ Ten pat.

${ }^{103}$ Ten pat.

${ }^{104}$ Ten pat.

${ }^{105}$ Ten pat. 
Sueigos narys Mykolas Krupavičius minejjo, kad sueigoje būta ir kitos nuomonès - siūlyta tiesiog ìsigyti mažus staliukus: „nes Seimo nariai neturi ant ko rašyt, ypač tie, kurie dirba. Laimingesni, kurie pateko $\mathfrak{i}$ dešinę, jie naudojasi langais, bet nelaimingieji likimo nustumti ị kairę net to neturi. Tad būtų gerai įsigyt tokių staliukų. " ${ }^{106}$ Vis dèlto Seimo nariai nepritarẻ kẻdžių keitimui ir parèmé principinę Finansų ir biudžeto komisijos poziciją - mažinti išlaidas. Regis, Seimo nariai ant tų pačių kẻdžių sẻdèjo iki pat Seimo paleidimo $1927 \mathrm{~m}$. balandžio 12 d. Beje, ši Seimo stenogramose užfiksuota diskusija dar kartą atskleidžia, kad Steigiamojo Seimo Seniūnų sueigos posėdžių protokolai turètų būti visapusiškai turtingas šaltinių masyvas, naudingas tarpdisciplininiams tyrimams.

Seniūnų sueiga sprendè Steigiamojo Seimo narių atlyginimo klausimą. $1921 \mathrm{~m}$. sausị Seniūnų sueigos nutarimu buvo pateiktas Steigiamojo Seimo narių atlyginimo ístatymo pakeitimo sumanymas, kuris Seimo prezidiumo sprendimu buvo perduotas Seimo Finansų ir biudžeto komisijai ${ }^{107} .1922 \mathrm{~m}$. balandị taip pat Seniūnų sueiga Steigiamojo Seimo Prezidiumui įteikè Steigiamojo Seimo narių atlyginimo isstatymo pakeitimo sumanymą ${ }^{108}$. Seniūnų sueiga kartu su Finansų ir biudžeto komisija bei visų frakcijų atstovais prièmè šio įstatymo pakeitimus ${ }^{109}$, iš esmès lèmusius Steigiamojo Seimo narių atlyginimo padidinimą. Svarstant ịstatymo pakeitimą kilo diskusija, ar teisingai atlikta įstatymo pateikimo procedūra, nes tai buvo įstatymas, keičiantis valstybès biudžetą, be to, buvo manančių, kad Seimo narių atlyginimo klausimas turètų kilti ne iš Seimo narių, o iš Ministrų Kabineto iniciatyvos. Svarstant ši ịstatymą vyko aršios diskusijos dẻl Seimo nario darbo vertinimo, Seimo nario ir paties Seimo autoriteto ${ }^{110}$.

${ }^{106}$ Ten pat.

${ }^{107} 1921 \mathrm{~m}$. sausio $25 \mathrm{~d}$., 57 posèdis. SSD.

$1081922 \mathrm{~m}$. balandžio 4 d., 192 posėdis. SSD.

${ }^{109} 1922 \mathrm{~m}$. balandžio $8 \mathrm{~d}$., 194 posèdis. SSD.

${ }^{110} 1922$ m. balandžio 11 d., 197 posèdis. SSD. 
Po kelerių metų, 1925 m. sausị, Lietuvos Respublikos Seimo rūmuose viešèjęs Latvijos Respublikos Seimo Pirmininkas Fridryhas Vesmanis (latv. - Frīdrihs Vesmanis) žurnalistams pasakojo su dideliu susidomejjimu apžiūrèjęs Lietuvos parlamento patalpas - Seimo posėdžių salę, komisijų patalpas, kurios Lietuvoje buvo erdvesnès nei Latvijos kolegų, taip pat apžiūrejjo biblioteką ir skaityklą. Labiausiai jị nustebino parlamento patalpų laikinumas ${ }^{111}$.

\section{Seniūnų sueiga paklojo pamatus Lietuvos Seimo dalyvavimui Tarpparlamentinès Sąjungos veikloje}

Seniūnų sueigai buvo patikèta spręsti Lietuvos Seimo narystès Tarpparlamentineje Sąjungoje klausimą. Paskutiniais Steigiamojo Seimo kadencijos metais, 1922 m. gegužès 4 d., Seimo Pirmininkas sulaukè Tarpparlamentinès Sąjungos generalinio sekretoriaus kvietimo Lietuvos parlamentui tapti sąjungos nariu ${ }^{112}$. Narystès klausimo svarstymas buvo perduotas Seniūnų sueigai, ši po konsultacijų su Užsienio reikalų ministerija rekomendavo Lietuvos Seimui tapti tarptautinès sąjungos nariu, nes tai „[...] bus dar viena priemonė Lietuvos nepriklausomybei ir jos padèčiai užsieny stiprinti [...]"113 Teigiamą sprendimą lèmè palyginti nedidelis narystès mokestis - 2000 Šveicarijos frankų, turintis laiduoti solidesnę naudą - Tarpparlamentinė Sąjunga siekè tarptautinius konfliktus spręsti arbitražo būdu, parlamentuose ir tarpparlamentiniuose kongresuose. Be to, 1889 metais ikurtos Tarpparlamentinès Sąungos narèmis jau buvo tapusios Lietuvos kaimynès - Estija, Suomija, Čekoslovakija, Lenkija. Nors Steigiamasis Seimas pritarè narystei šioje organizacijoje, tačiau realią veiklą joje igyvendino kitų kadencijų Lietuvos Respublikos Seimas. 1923 metais pirmą kartą Lietuvos Respublikos Seimo delegacija dalyvavo 21-oje

${ }^{111}$ Saeimas priekšsēēetāja viesošanās Lietuvā. Latvijas Kareivis. 10.01.1925, Nr. 7.

1121922 m. rugpjūčio 17 d., 242 posèdis. $S S D$.

${ }^{113} 1922$ m. rugpjūčio $17 \mathrm{~d}$., 242 posèdis. $S S D$. 
Tarpparlamentinès Sąjungos konferencijoje Kopenhagoje. Joje dalyvavo Lietuvos Seimo delegacija, kurią sudarè liaudininkų lyderis Mykolas Sleževičius ir krikščionių demokratų atstovai Kazimieras Jokantas ir Pranas Viktoras Raulinaitis ${ }^{114} .1924$ m. vasario 20 d. Lietuvos Respublikos Seimo nariai oficialiai įsteigè Tarpparlamentinès Sąjungos Lietuvos grupę ${ }^{115}$.

\section{Steigiamojo Seimo nariai, dirbę Seniūnų sueigoje}

Deja, dèl prastos XX a. Lietuvos Respublikos Seimo istorijos šaltinių būklès neįmanoma tiksliai rekonstruoti Steigiamojo Seimo narių kaitos Seniūnų sueigoje, tačiau turimi šaltiniai leidžia sudaryti sąrašą parlamentarų, kuriems buvo patikèta dirbti šiame struktūriniame Seimo vienete. Steigiamojo Seimo narių biografijose ir biogramose lakoniškai užsimenama, kad parlamentaras buvo Seniūnų sueigos narys, nors dažnai yra nurodoma paskyrimo data, tačiau labai retai nurodoma, iki kada jis šias pareigas ejjo. Žemiau pateikiama susisteminta informacija, kuri galètų pasitarnauti biografijų rengèjams.

Nors iš viso Steigiamojo Seimo Seniūnų sueigą sudare 19 narių, per visą Steigiamojo Seimo kadenciją Seniūnų sueigos nariais yra buvę 37 parlamentarai: 17 Krikščionių demokratų bloko atstovų, 11 Valstiečių liaudininkų bloko atstovų, 3 socialdemokratai, 5 Žydų frakcijos atstovai ir 1 lenkų atstovas. Visi jie paliko ryškų įspaudą Lietuvos parlamento istorijoje. Seniūnų sueigos nariais buvo ryškūs frakcijų atstovai - lyderiai, igiję skirtingos visuomeninès ir politinès patirties, skirtingo išsilavinimo ir skirtingų profesijų atstovai: 8 teisininkai (vienas iš jų taikos teisèjas), 7 medikai (vienas iš jų

${ }^{114}$ Seimas gavo pakvietimą dalyvauti per savo atstovus 21 tarpparlamentarinèje konferencijoje. Lietuvos žinios. 1923, liepos 28; Union interparlementaire. Compterendue de la XXI Conferonce tenue a Copenhague du 15 au 17 Aout 1923. Genève, Bureau interparlementaire. Lietuvos žinios. 1924, kovo 1.

115 Tarpparlamentinès Sajungos Lietuvos skyriaus steigimas. Lietuvos žinios. 1924, vasario 23. 
farmacininkas), 4 dvasininkai, 3 ekonomistai, 3 agronomai, 2 filosofai, 2 inžinieriai, 2 pedagogai, 2 darbininkai, 1 kariškis (būsimasis teisininkas), 1 žurnalistas. Dauguma jų turèjo visuomeninio darbo patirties, dalyvavo lietuvių konferencijose, nubréžusiose Lietuvos valstybès atkūrimo trajektorijas, kai kurie iš jų buvo dirbę atkurtos Lietuvos valstybès institucijose. Vèliau dalis jų ịsiliejo ị valstybės tarnybą, net 5 buvę Seniūnų sueigos nariai dirbo Lietuvos diplomatineje tarnyboje.

Net 8 Seniūnų sueigos nariai dirbo keturiose Seimo kadencijose, 7 nariai - trijose, 7 nariai - dviejose, mažiau nei pusė - 15 Seniūnų sueigos narių dirbo tik Steigiamajame Seime. 4 Seniūnų sueigos nariai ejo Lietuvos Respublikos Seimo Pirmininko pareigas (Aleksandras Stulginskis, Justinas Staugaitis, Antanas Tumėnas ir Jonas Staugaitis). Tarp Steigiamojo Seimo Seniūnų sueigos narių 8 buvę Lietuvos Valstybès Tarybos nariai (Kazimieras Bizauskas, Aleksandras Stulginskis, Justinas Staugaitis, Jonas Vailokaitis, Valdemaras Vytautas Čarneckis, Eliziejus Draugelis, Nachmanas Rachmilevičius, Simonas Rozenbaumas), 4 iš jų buvo $1918 \mathrm{~m}$. vasario $16 \mathrm{~d}$. Lietuvos Nepriklausomybès Akto signatarai (Kazimieras Bizauskas, Justinas Staugaitis, Aleksandras Stulginskis ir Jonas Vailokaitis). Patirtis, igyta dirbant Lietuvos Valstybès Taryboje, pravertė jiems ir parlamentineje veikloje. 3 Seniūnų sueigos nariai èjo ministro pirmininko pareigas (Mykolas Sleževičius, Kazys Grinius ir Antanas Tumėnas), net 12 Steigiamojo Seimo Seniūnų sueigos narių èjo ministro pareigas ịvairiose Ministrų Kabinetuose, kai kurie iš jų šias pareigas èjo daugiau nei vieną kartą. 2 Seniūnų sueigos nariai vèliau èjo Lietuvos Respublikos prezidento pareigas (Aleksandras Stulginskis ir Kazys Grinius).

Idomu atkreipti dèmesí, kad tik 3 Seniūnų sueigos nariai (neskaitant Seimo Prezidiumo narių, taip pat ịejusių i sueigą) joje dirbo visą Steigiamojo Seimo kadenciją - tai krikščionių demokratų atstovai Kazimieras Ambrozaitis, Kazimieras Jokantas ir Zigmas Starkus. Iš Steigiamojo Seimo Prezidiumo narių visą kadenciją dirbo Seimo pirmininkas Alek- 
sandras Stulginskis, vicepirmininkai Jonas Staugaitis ir Justinas Staugaitis bei sekretorius, turintis patariamąji balsą, Bronislovas Cirtautas.

\section{Krikščionių demokratų bloko atstovai:}

Kazimieras AMBROZAITIS (1920 m. gegužès 22 d. - 1922 m. lapkričio $13 \mathrm{~d}$.);

Kazimieras BIZAUSKAS (1920 m. gegužès 22 d. - 1920 m. spalio 1 d. ${ }^{116}$ - dar būdamas Seniūnų sueigos nariu, $1920 \mathrm{~m}$. birželio $19 \mathrm{~d}$. pradejo eiti švietimo ministro pareigas);

Antanas BULIONIS (1921 m. liepos 9 d. ${ }^{117}$ - 1922 m. lapkričio 13 d.; i šias pareigas buvo paskirtas kaip pavaduojantis narys);

Valdemaras Vytautas ČARNECKIS (1921 m. vasario $15 \mathrm{~d}{ }^{118}$ 1921 m. liepos 9 d.; Seniūnų sueigoje nebedalyvaudavo jau anksčiau, o $1921 \mathrm{~m}$. balandžio 15 d. buvo paskirtas Lietuvos Respublikos nepaprastuoju pasiuntiniu ir igaliotuoju ministru Vašingtone);

Eliziejus DRAUGELIS (1921 m. liepos 9 d. ${ }^{119}$ - $1922 \mathrm{~m}$. lapkričio 13 d.; i šias pareigas buvo paskirtas kaip pavaduojantis narys);

Kazimieras JOKANTAS (1920 m. gegužès 22 d. - 1922 m. lapkričio 13 d.);

Vladas JURGUTIS (1921 m. vasario $15 \mathrm{~d} .{ }^{120}$ - [1922 m. kovo 3 d.] - nepavyko nustatyti tikslios datos, kada pasitraukè iš Seniūnų sueigos, $1922 \mathrm{~m}$. sausio $5 \mathrm{~d}$. tapo užsienio reikalų ministru, o $1922 \mathrm{~m}$. kovo $3 \mathrm{~d}$. pasitraukè iš Steigiamojo Seimo);

Julius KAUPAS (1921 m. liepos 9 d. ${ }^{121}$ - 1922 m. lapkričio 13 d.; i ̌ šias pareigas buvo paskirtas kaip pavaduojantis narys);

1161920 m. spalio $1 \mathrm{~d}$., 47 posedis. SSD.

${ }^{117} 1921 \mathrm{~m}$. liepos 9 d., 117 posėdis. SSD.

$1181921 \mathrm{~m}$. vasario $15 \mathrm{~d}$., 63 posèdis. $S S D$.

${ }^{119} 1921 \mathrm{~m}$. liepos 9 d., 117 posèdis. SSD.

${ }^{120} 1921 \mathrm{~m}$. vasario $15 \mathrm{~d}$., 63 posèdis. $S S D$.

${ }^{121} 1921 \mathrm{~m}$. liepos 9 d., 117 posèdis. SSD. 
Mykolas KRUPAVIČIUS (1920 m. gegužès 22 d. - 1921 m. vasario $15 \mathrm{~d}^{122}$ );

Antanas MILČIUS, Seimo Prezidiumo narys - antrasis sekretorius, turintis sprendžiamąji balsą (1921 m. spalio $25 \mathrm{~d}$. - $1922 \mathrm{~m}$. lapkričio $13 \mathrm{~d}$.);

Petras RADZEVIČIUS, Seimo Prezidiumo narys - antrasis sekretorius, turintis sprendžiamąji balsą (1920 m. gegužès 17 d. - $1922 \mathrm{~m}$. spalio $25 \mathrm{~d}$.); $1921 \mathrm{~m}$. rugsèjo $13 \mathrm{~d}$. buvo svarstomas jo atsistatydinimo klausimas, bet Seimas jo netenkino ${ }^{123}$;

Zigmas STARKUS (1920 m. gegužès 22 d. - 1922 m. lapkričio 13 d.);

Justinas STAUGAITIS, Seimo Prezidiumo narys - antrasis vicepirmininkas (1920 m. gegužès 17 d. - 1922 m. lapkričio 13 d.);

Aleksandras STULGINSKIS, Seimo Prezidiumo narys - Steigiamojo Seimo pirmininkas (1920 m. gegužès 15 d. - 1922 m. lapkričio 13 d.);

Antanas ŠMULKŠTYS (1922 m. birželio 23 d. ${ }^{124}$ - $1922 \mathrm{~m}$. lapkričio 13 d. - Seimo stenogramoje įrašyta: „I Seniūnų Sueigą vieton išstojusio Jono Vailokaičio - atstovą Šmulkštị “ ${ }^{125}$. Steigiamojo Seimo kadencijoje dirbo Antanas Šmulkštys ir Vincas Šmulkštys, nors nèra paaiškinta, kuris iš jų, tačiau tikètina, kad Seniūnų sueigos nariu tapo ryškesnis krikščionių demokratų atstovas - Antanas Šmulkštys);

Antanas TUMĖNAS $\left(1920 \mathrm{~m}\right.$. spalio $1 \mathrm{~d} .{ }^{126}$ - $1921 \mathrm{~m}$. vasario 15 d. $^{127}$ );

${ }^{122} 1921 \mathrm{~m}$. vasario $15 \mathrm{~d}$., 63 posèdis. $S S D$.

${ }^{123} 1921 \mathrm{~m}$. rugsèjo $13 \mathrm{~d}$., 122 posėdis. SSD.

${ }^{124} 1922$ m. birželio 23 d., 215 posèdis. SSD.

${ }^{125}$ Ten pat.

${ }^{126} 1920 \mathrm{~m}$. spalio $1 \mathrm{~d}$., 47 posèdis. SSD.

${ }^{127} 1921 \mathrm{~m}$. vasario $15 \mathrm{~d}$., 63 posèdis. $S S D$. 
Jonas VAILOKAITIS (1920 m. gegužès 22 d. - [1922 m. kovo 3 d. ${ }^{128}$ - nepavyko nustatyti tikslios datos, kada pasitraukè iš Seniūnų sueigos, tačiau žinoma, kad 1922 m. kovo 3 d. pasitraukẻ iš Steigiamojo Seimo).

\section{Lietuvos socialistų liaudininkų demokratų ir Lietuvos valstiečių sąjungos frakcijų bloko atstovai:}

Juozas BUZELIS (1921 m. balandžio 19 d. ${ }^{129}$ - 1922 m. lapkričio 13 d.);

Kazys GRINIUS (1920 m. gegužès 22 d. - 1920 m. liepos 5 d. ${ }^{130}$ dar būdamas Seniūnų sueigos nariu, $1920 \mathrm{~m}$. birželio $19 \mathrm{~d}$. pradèjo eiti ministro pirmininko pareigas);

Jonas KRIŠČIŪNAS (1921 m. liepos 9 d. ${ }^{131}$ - 1922 m. lapkričio 13 d. - i šias pareigas buvo paskirtas kaip pavaduojantis narys);

Vladas LAŠAS (1920 m. liepos 5 d. ${ }^{132}$ - 1920 m. rugpjūčio 13 d. ${ }^{133}$ );

Jonas MAKAUSKAS (1920 m. liepos 5 d. ${ }^{134}$ - $1922 \mathrm{~m}$. lapkričio 13 d. $\left.^{135}\right)$;

Ladas NATKEVIČIUS, Seimo Prezidiumo narys - pirmasis sekretorius, turintis sprendžiamąji balsą (1920 m. gegužès 17 d. $1922 \mathrm{~m}$. vasario $21 \mathrm{~d}$.);

Motiejus PETRAUSKAS (1920 m. gegužès 22 d. - 1920 m. liepos 5 d. $\left.^{136}\right)$;

${ }^{128} 1922$ m. birželio 23 d., 215 posèdis. SSD.

${ }^{129} 1920$ m. balandžio 19 d., 81 posèdis. $S S D$.

${ }^{130} 1920 \mathrm{~m}$. liepos 5 d., 23 posedis. SSD.

${ }^{131} 1921 \mathrm{~m}$. liepos 9 d., 117 posèdis. SSD.

$1321920 \mathrm{~m}$. liepos 5 d., 23 poseddis. SSD.

${ }^{133} 1920$ m. rugpjūčio 13 d., 39 posèdis. $S S D$.

${ }^{134} 1920 \mathrm{~m}$. liepos 5 d., 23 posédis. SSD.

${ }^{135} 1920$ m. rugpjūčio 13 d., 39 poseddis. $S S D$.

${ }^{136} 1920 \mathrm{~m}$. liepos 5 d., 23 posèdis. $S S D$. 
Vytautas RAČKAUSKAS, Seimo Prezidiumo narys - pirmasis sekretorius, turintis sprendžiamąji balsą $\left(1922 \mathrm{~m}\right.$. kovo $2 \mathrm{~d} \cdot{ }^{137}-1922 \mathrm{~m}$. lapkričio 13 d.) - jo darbas Seniūnų sueigoje labai komplikuotas, net keliose Seimo stenogramose minimas jo paskyrimas Seniūnų sueigos nariu: $1920 \mathrm{~m}$. rugpjūčio $13 \mathrm{~d}$., ${ }^{138}, 1920 \mathrm{~m}$. spalio $15 \mathrm{~d} .{ }^{139}, 1921 \mathrm{~m}$. liepos $9 \mathrm{~d}$. - $\mathfrak{i}$ šias pareigas buvo paskirtas kaip pavaduojantis narys $^{140}$, - kol galiausiai 1922 m. kovo 2 d. tapęs Seimo Prezidiumo nariu automatiškai tapo ir Seniūnų sueigos nariu).

Mykolas SLEŽEVIČIUS (1920 m. rugpjūčio 13 d. ${ }^{141}$ - 1921 m. balandžio 19 d. ${ }^{142}$ );

Jonas STAUGAITIS, Seimo Prezidiumo narys - pirmasis vicepirmininkas (1920 m. gegužès 17 d. - 1922 m. lapkričio 13 d.);

Matas UNTULIS (1920 m. gegužès 22 d. - 1920 m. spalio 15 d. ${ }^{143}$ ).

\section{Socialdemokratų frakcijos atstovai:}

Bronislovas CIRTAUTAS, Seimo Prezidiumo narys - sekretorius, turintis patariamąji balsą (1920 m. gegužès 17 d. - 1922 m. lapkričio 13 d.);

Stasys DIGRYS (nuo $1921 \mathrm{~m}$. liepos 9 d. ${ }^{144}$ - $1922 \mathrm{~m}$. lapkričio 13 d. $)^{145}$;

${ }^{137} 1922$ m. kovo 2 d., 177 posėdis. SSD.

${ }^{138} 1920 \mathrm{~m}$. rugpjūčio $13 \mathrm{~d}$., 39 posèdis. $S S D$.

${ }^{139} 1920 \mathrm{~m}$. spalio $15 \mathrm{~d}$., 51 posėdis. SSD.

${ }^{140} 1921 \mathrm{~m}$. liepos 9 d., 117 posėdis. SSD.

${ }^{141} 1920$ m. rugpjūčio 13 d., 39 posèdis. $S S D$.

$1421920 \mathrm{~m}$. balandžio $19 \mathrm{~d} ., 81$ posėdis. SSD.

${ }^{143} 1920 \mathrm{~m}$. spalio $15 \mathrm{~d}$., 51 posèdis. SSD.

${ }^{144} 1921 \mathrm{~m}$. liepos 9 d., 117 posèdis. SSD.

${ }^{145}$ Istorikas Gintaras Mitrulevičius nurodo, kad Stasys Digrys „Nuo 19210902 kurị laiką laikinai atstovavo LSDP frakcijai StS Seniūnų sueigoje.“, tačiau Seimo posėdžių stenogramos byloja, kad S. Digrys Seniūnų sueigos nariu tapo $1921 \mathrm{~m}$. liepos 9 d., žr.: Mitrulevičius, Gintaras, Digrys, Stasys. Lietuvos Steigiamojo Seimo (1920-1922 metu) nariu biografinis žodynas. Sud. Aivas Ragauskas, Mindaugas Tamošaitis, Vilnius: Vilniaus pedagoginio universiteto leidykla, 2006, p. 133. 
Kazimieras VENCLAUSKIS (1920 m. gegužès 22 d. - 1921 m. liepos 9 d.) - $1921 \mathrm{~m}$. gegužès $20 \mathrm{~d}$. - Socialdemokratų frakcija protestuodama atšaukè savo atstovus iš visų komisijų, Seimo Prezidiumo ir Seniūnų sueigos, iš Seniūnų sueigos buvo atšauktas Kazimieras Venclauskis, tačiau netrukus vietoje jo buvo deleguotas Stasys Digrys ${ }^{146}$.

\section{Žydų frakcijos atstovai:}

Ozeris FINKELŠTEINAS (1920 m. liepos 5 d. ${ }^{147}$ - $1921 \mathrm{~m}$. balandžio 5 d. ${ }^{148}$ );

Naftalis FRIDMANAS, Seimo Prezidiumo narys - sekretorius, turintis patariamąji balsą (1920 m. gegužès 17 d. - $1921 \mathrm{~m}$. rugpjūčio $30 \mathrm{~d}$., tą dieną buvo nutraukti jo igaliojimai, nors jis mirè anksčiau 1921 m. gegužès 5 d.);

Nachmanas RACHMILEVIČIUS, Seimo Prezidiumo narys - sekretorius, turintis patariamąji balsą (1921 m. lapkričio 8 d. - 1922 m. lapkričio 13 d.);

Simonas ROZENBAUMAS (1921 m. balandžio $5 \mathrm{~d} .{ }^{149}-1922 \mathrm{~m}$. lapkričio 13 d.);

Maksas SOLOVEIČIKAS (1920 m. gegužès 22 d. - 1920 m. liepos 5 d. ${ }^{150}$ - dar būdamas Seniūnų sueigos nariu, 1920 m. birželio 19 d. pradejjo eiti Žydų reikalų ministro pareigas).

\section{Lenku atstovas:}

Antanas ŠNIELEVSKIS (1920 m. gegužès 22 d. - 1922 m. lapkričio 13 d. - Lenkų frakcijos nariai nuo $1921 \mathrm{~m}$. liepos 9 d. Steigiamojo Seimo darbe nebedalyvavo, nors Seimo nario mandatą išsaugojo. Nors Lenkų atstovas formaliai ir toliau buvo Seniūnų sueigos nariu, tačiau jos veikloje nedalyvavo.)

${ }^{146} 1921$ m. gegužès 20 d., 94 posėdis. SSD.

${ }^{147} 1920 \mathrm{~m}$. liepos 5 d., 23 posèdis. SSD.

${ }^{148} 1921 \mathrm{~m}$. balandžio $5 \mathrm{~d}$., 77 posèdis. SSD.

149 Ten pat.

${ }^{150} 1920$ m. liepos 5 d., 23 posèdis. SSD. 


\section{Išvados}

1. Steigiamajame Seime Seniūnų sueiga buvo sudaryta ne iš karto, tik 1922 m. gegužès 22 d., 6-ojo Steigiamojo Seimo posėdžio metu, po to, kai jau buvo patvirtintas Seimo darbą reglamentavęs Laikinasis Steigiamojo Seimo statutas. Seniūnų sueigos steigimą inicijavo Steigiamojo Seimo Prezidiumas. Pagrindiné Seniūnų sueigos užduotis padèti spręsti opiausius Seimo darbo organizavimo klausimus.

2. Seniūnų sueigą sudarè Steigiamojo Seimo Prezidiumas ir 12 frakcijų atstovų. Seniūnų sueigos pirmininku buvo išrinktas Jonas Staugaitis. Nors iš viso Steigiamojo Seimo Seniūnų sueigą sudarè 19 narių, tačiau per visą Steigiamojo Seimo kadenciją Seniūnų sueigos nariais yra buvę 37 parlamentarai: 17 Krikščionių demokratų bloko atstovų, 11 Valstiečių liaudininkų bloko atstovų, 3 socialdemokratai, 5 Žydų frakcijos atstovai ir 1 lenkų atstovas. Seniūnų sueigos nariai dažnai keisdavosi. Seniūnų sueigos nariais buvo ryškūs frakcijų atstovai - lyderiai, igiję skirtingos visuomeninès ir politinès patirties, skirtingo išsilavinimo ir profesijų atstovai. Dauguma jų turejjo visuomeninio darbo patirties, dalyvavo lietuvių konferencijose, nubrèžusiose Lietuvos valstybès atkūrimo trajektorijas, kai kurie iš jų buvo dirbę atkurtos Lietuvos valstybès institucijose. Vèliau dalis jų ịsiliejo ị valstybès tarnybą.

3. Seniūnų sueiga sprendè svarbiausius Steigiamojo Seimo darbo organizavimo klausimus: Seimo posėdžių organizavimo, Seimo statuto, Seimo narių darbo sąlygų klausimus, teikè siūlymus Seimui dèl Seimo komisijų veiklos, komisijų sujungimo, narių komisijose skaičiaus, teikè siūlymus dèl darbotvarkès pakeitimų, esant reikalui nustatydavo darbotvarkès prioritetus. Seniūnų sueiga svarstė klausimą dèl valstybės biudžeto svarstymo tvarkos ir nustatẻ biudžeto svarstymo eigą. Seniūnų sueigoje buvo derinami, vèliau Seime priimami ir Steigiamojo Seimo vardu platinami atsišaukimai, raginantys piliečius 
susitelkti krašto gynybai ar palaikyti Lietuvos ekonomiką ìsigyjant valstybès platinamus paskolos lakštus. Bene svarbiausias Steigiamojo Seimo Seniūnų sueigos darbas - Lietuvos Steigiamojo Seimo statuto redakcija. Seniūnų sueiga sprendè Seimo plenarinių posėdžių pertraukos klausimą, o pertraukos metu prižiūrèjo įstatymų vykdymą, siūlydavo Seimo plenarinių posėdžių laiką ir posėdžių periodiškumą, svarstė nelietuvių kalbos vartojimo plenarinių posėdžių metu klausimą, inicijavo parlamento bibliotekos steigimą, rekomendavo sudaryti palankesnes darbo sąlygas Seimo nariams, inicijuodavo atlyginimų Seimo nariams didinimą, Seniūnų sueiga paklojo pamatus Lietuvos Seimo narystei Tarpparlamentinejje Sąjungoje.

\section{CONFERENCE OF CHAIRS OF THE CONSTITUENT SEIMAS OF THE LITHUANIA: GUIDELINES FOR THE ACTIVITIES OF THE SENIOR CONVENTION}

\section{Summary}

2020 is an exceptional year in the history of the Lithuanian state; this year marks the 100th anniversary of the Republic of Lithuania. On May 15, 1920, the Constituent Seimas, meeting in the provisional capital of Lithuania in Kaunas, solemnly proclaimed the independence of the State of Lithuania and, on behalf of all Lithuanian citizens, declared State of Lithuania as a democratic republic. The article seeks to examine the organization of the work of the first Lithuanian Parliament, elected in general and democratic elections. The purpose of the article is to review the circumstances of the formation of the Conference of Chairs of Constituent Seimas of the Lithuania (1920-1922), to determine the composition of the Con- ference of Chairs and the change of its members, to describe the collective portrait of them, to review the range of issues discussed at the Conference of Chairs. In the Constituent Seimas, the Conference of Chairs was formed only on 22 of May in 1922, at the sixth meeting of the Founding Seimas, after the provisional Statute of the Constituent Seimas had already been approved. The establishment of the Conference of Chairs was initiated by the Presidium of the Constituent Seimas. The main task of the Conference of Chairs was to help solve the most sensitive issues of the organization of the work of the Seimas. The Conference of Chairs consisted of the members of Presidium (seven members) of the Constituent Seimas and of 12 rep- 
resentatives of different political groups. as members of the Conference of Chairs. First Deputy Speaker of the Constituent By party affiliation, there were 17 - repSeimas Jonas Staugaitis become Chairman resentatives of the Christian Democratic of the Conference of Chairs. Although the Bloc, 11 - representatives of the Peasant Conference of Chairs of the Constituent people's bloc, 3 - Social Democrats, 5 Seimas consisted at all of 19 members, representatives of the Jewish Group and during the entire term of the Constituent 1 - representatives of the Polish group. Seimas there were 37 parliamentarians

Keywords: Constituent Seimas of the Lithuania, Conference of Chairs, Board of the Seimas, Statute of the Seimas, political groups, parliament.

Iteikta 2020 m. rugsèjo $29 d$. 